\title{
4. TECTONIC WINDOW INTO GABBROIC ROCKS OF THE MIDDLE OCEANIC CRUST IN THE MARK AREA NEAR SITES 921-9241
}

\author{
Jeffrey A. Karson² and Róisín M. Lawrence ${ }^{2}$
}

\begin{abstract}
Extensive exposures of gabbroic rocks, inferred to represent mid-crustal intervals of the oceanic crust, crop out on the western median valley wall of the spreading segment of the Mid-Atlantic Ridge immediately south of the Kane Transform. Surface exposures of the gabbroic rocks have been mapped by numerous submersible dives, deeply towed camera transects, and sidescan sonar surveys, making this region one of the most intensively studied areas of the mid-ocean ridge system. Recent drilling in this tectonic window at Sites 921-924 provides a new perspective on the architecture and mode of accretion of mid-crustal rocks of the oceanic crust.

Surface studies show that the gabbroic rocks crop out in an area that extends at least $15 \mathrm{~km}$ along the ridge axis and 8-10 $\mathrm{km}$ normal to the ridge axis. The median valley wall of the Mid-Atlantic Ridge here is essentially a dip-slope on a major crustal detachment fault. This low-angle normal fault zone has been cut by numerous steeply dipping normal faults that impart a stairstep morphology to the terrain. Basaltic pillow lavas crop out at the top of the median valley wall and probably represent upper crustal rocks that formed structurally above the gabbroic units. To the east, the median valley floor of the Mid-Atlantic Ridge is dominated by relatively young pillow lavas and an extensive neovolcanic ridge. These lavas overlie the detachment footwall, and are probably the surface expression of dikes and plutonic bodies that cut the detachment at depth.

Gabbroic and related rocks recovered from Sites 921 to 924 indicate that the mid-crustal terrain exposed in this tectonic window was assembled as a collage of relatively small (less than about $1 \mathrm{~km}$ across) plutons. Individual plutons have been variably deformed and metamorphosed, and subsequently intruded by later plutons and dikes. Thus, whereas surface exposures show evidence of major faulting over the past $0.5 \mathrm{~m} . \mathrm{y}$., subsurface data from Ocean Drilling Program cores indicate a more continuous style of synkinematic intrusion and crustal stretching. These processes may be broadly coeval expressions of slow seafloor spreading in this environment. Exposures of similar crustal levels in the adjacent Kane Transform suggest a similar pattern of accretion. This type of spreading may be common at ridge-transform intersections and other places on slow-spreading ridges with very low or episodic magma budgets.
\end{abstract}

\section{INTRODUCTION}

The oceanic crust is traditionally considered to consist of a vertical sequence of magmatic rock units including (1) upper crustal units, $1-2 \mathrm{~km}$ thick, consisting of basaltic pillow lavas underlain by a sheeted diabase dike complex, and (2) middle to lower crustal units, typically $2-4 \mathrm{~km}$ thick, composed of a plutonic suite of gabbroic and lesser ultramafic rocks. These magmatic units are variably deformed and metamorphosed and lie atop upper mantle peridotites that have been depleted by partial melting. This sequence is inferred from oceanic seismic studies (Bratt and Purdy, 1984; Vera et al., 1990) and the acoustic properties of rocks sampled from the seafloor (Fox, 1972; Christensen and Salisbury, 1975; Karson and Fox, 1986; Christensen, 1982). This distinctive assemblage is correlated with a similar layered sequence of ophiolite complexes (Moores and Vine, 1971; Casey et al., 1981; Nicolas, 1989), on-land exposures of fossil oceanic lithosphere.

Whereas there have been extensive studies of mid-ocean ridge basaltic terrains and the geochemistry and petrology of mid-ocean ridge basalts, relatively little is known of the middle to lower oceanic crust. Exposures of these rock units are limited to areas of major faulting (referred to as "tectonic windows") found along oceanic fracture zones, the median valley walls of some slow-spreading ridge segments, and propagating rift tips. Detailed studies of rock units exposed in tectonic windows provide important insights into the internal structure and composition of oceanic crust. Despite the systemat-

'Karson, J.A., Cannat, M., Miller, D.J., and Elthon, D. (Eds.), 1997. Proc. ODP, Sci. Results, 153: College Station, TX (Ocean Drilling Program).

${ }^{2}$ Department of Geology, Duke University, Durham, NC 27708-0230, U.S.A jkarson@geo.duke.edu ic layered structure inferred from seismic refraction studies, direct observations show that slow-spreading crust is composed of a heterogeneous assemblage of igneous to variably deformed and metamorphosed mafic and ultramafic rock units (Karson et al., 1987; Brown and Karson, 1988; Karson, 1990; Cannat, 1993; Cannat et al., 1995).

Leg 153 was the first attempt at offset drilling in the plutonic foundation of slow-spreading crust of the Mid-Atlantic Ridge. Drilling penetrated deep crustal and upper mantle rocks in a tectonic window in the oceanic crust that has been extensively studied using submersibles as well as geophysical surveys. Scientific results from these multidisciplinary investigations indicate that drilling and submersible studies are complementary techniques required to begin to understand the complex three-dimensional architecture of significant volumes of oceanic plutonic rocks. Whereas both techniques have their own strengths and limitations, together they reveal previously unknown relationships that could not be determined from either approach alone. Drilling during Leg 153 and extensive submersible studies of the drill sites provide an excellent example of how such an integrated program can contribute to the understanding of crustal accretion processes. In this regard, drilling is viewed as just one member of a family of investigations in the study of the geology of key areas of the oceanic crust. Site survey studies using submersibles are seen as necessary investigations that can make important contributions both before and after drilling.

\section{SEAFLOOR SPREADING ON THE MID-ATLANTIC RIDGE}

Two primary processes interact in a complex way along midocean ridge spreading centers (Macdonald, 1986): (1) magmatic con- 
struction that builds the oceanic crust, and (2) faulting that thins and disrupts the crust. In general, the relationship between these two processes is governed by the "magma budget," defined as the volume of magma per unit of plate separation (Karson and Winters, 1992), Where the magma budget is relatively high, spreading is accommodated mainly by magmatic accretion, and disruption of the igneous crustal structure is relatively minor. Where the magma budget is low, spreading is accommodated primarily by mechanical stretching and thinning of the existing crust and lithosphere. The deformation can be interrupted periodically by magmatic events resulting in complex geological relations between variably deformed crustal and upper mantle rock units.

At fast-spreading ridges, where a continuous magma supply is thought to exist in subaxial magma chambers (Detrick et al., 1987; Toomey et al., 1990; Sinton and Detrick, 1992), the magma budget appears to be relatively high, and plate separation is accommodated almost entirely by magmatic accretion. On slow-spreading ridges, the magma budget is more variable. In some places, magmatic construction appears to dominate. Elsewhere, the neovolcanic zone and upper crustal basaltic rock units are discontinuous, and faulting plays a much more important role. In some places, major faults expose mafic plutonic rocks of the middle to deep crust and locally serpentinized upper mantle material. The details of the geologic history of rocks exposed in these tectonic windows may provide the key to understanding the relationships between magmatism and mechanical extension in slow-spreading environments.

Especially away from hot spots, like Iceland or the Azores, the magma budget appears to be highly variable and locally so low that, over the past 1 m.y., construction has not kept pace with plate separation (Karson and Winters, 1992). Without the creation of new magmatic crust, the existing crust and lithosphere will be stretched and thinned. The longer stretching occurs without substantial magmatic accretion, the more severe the disruption of the pre-existing crustal structure will be. The most highly stretched regions have many characteristics in common with highly extended continental terrains and metamorphic core complexes of the Cordilleran region (Lister and Davis, 1989) and can be regarded as an oceanic core complexes (Brown and Karson, 1988; Karson, 1990; Mutter and Karson, 1992).

Juxtaposition of highly faulted and thinned crust with younger, much less deformed terrains suggests that the magma supply may be episodic on time scales of tens to hundreds of thousands of years. Along slow-spreading ridges, it appears that the magmatic units of the oceanic crust are produced by periodic constructional events separated by periods when plate separation is largely or solely accommodated by stretching and thinning of the axial lithosphere. In an extreme case, where the magma budget is very low or negligible, upper mantle material beneath ridge axes is faulted, hydrated, and serpentinized as it rises and spreads laterally (Hess, 1962; Cannat, 1993). This gives rise to extensive serpentinite core complexes that are punctuated by subordinate mafic plutons and dikes and capped by discontinuous basaltic lava flows (Brown and Karson, 1988; Cannat et al., 1995). In a less extreme case, spreading may be accomplished by more or less continuous crustal stretching accompanied by synkinematic intrusions.

Thus, slow-spreading crust appears to consist of a lumpy assemblage of magmatic units and serpentinite masses, on the order of few kilometers to a few tens of kilometers across, that have been dismembered to varying degrees by faulting. This type of internal structure may be expressed in complex patterns of seismic reflectors seen in multichannel seismic reflection profiles of slow-spreading crust (Mutter and Karson, 1992; Morris et al., 1993).

In this paper, we describe the tectonic setting of middle to lower crustal rocks exposed by major faulting on the Mid-Atlantic Ridge near the Kane Transform (MARK area) at $24^{\circ} \mathrm{N}$ latitude. The crustal section exposed in this major tectonic window has been investigated by submersibles, side-scan sonar systems, deeply towed cameras, and recently by Ocean Drilling Program (ODP) drilling. The combined surface and subsurface information provides a sense of the threedimensional architecture of this crustal section and its evolution.

\section{THE MARK AREA}

The Mid-Atlantic Ridge south of the Kane Transform (MARK area) extends for at least $400 \mathrm{~km}$ without being interrupted by major transforms. The ridge axis is characterized by symmetrical and asymmetrical morphologic segments (Segments 1-3; Fig. 1) that resemble graben and half-graben, similar to other parts of the Mid-Atlantic Ridge (Purdy et al., 1990; Sempéré et al., 1990). The axial valley floor of the individual segments (deeper than $\sim 3500$ m below sea level [mbsl]) varies in width from 14 to $20 \mathrm{~km}$, and the total relief of the rift valley ranges from less than 1 to more than $4 \mathrm{~km}$. The median valley floor tends to be shallowest near the segment midpoints and deepest near their ends, where they are linked by areas of obliquely trending bathymetric lineaments referred to as discordant zones (Macdonald et al., 1988; Grindlay et al., 1991). In the northernmost segment of the MARK area, the median valley floor deepens and broadens northward to $>6100 \mathrm{mbsl}$ in the "nodal basin" marking the intersection with the Kane Fracture Zone (Fig. 1). Gravity data obtained here and elsewhere along the Mid-Atlantic Ridge axis suggest that such segments may reflect the focusing of the ridge's magma supply beneath segment centers, with attenuation of magmatism near the segment ends (Kuo and Forsyth, 1988; Lin et al., 1990; Patriat et al., 1991; Deplus et al., 1992).

In the MARK area, extending about $100 \mathrm{~km}$ south of the Kane Transform, morphologic segments have been shown to correlate directly with surface geology (Karson et al., 1987; Brown and Karson, 1988; Kong et al., 1989), the seismic expression of the axial crust (Detrick and Purdy, 1980; Cormier et al., 1984; Purdy and Detrick, 1986; Detrick et al., 1990; Mutter and Karson, 1992), and gravity data (Morris and Detrick, 1991).

The MARK area is currently the most comprehensively studied portion of the Mid-Atlantic Ridge. Initial investigations of the MidAtlantic Ridge in this area began in the late 1960s and included conventional wide-beam echo-sounding surveys and dredging (Miyashiro et al., 1970, 1971; van Andel et al., 1969; Fox, 1972). As part of the site survey for Leg 106, a SeaBeam bathymetric map (Detrick et al., 1988) was produced and magnetic (Schulz et al., 1988) and gravity (Morris and Detrick, 1991) data were collected. From a separate cruise, SeaMARC I side-scan sonar data provided additional information on the morphology and geology of the median valley floor (Kong et al., 1989). Magnetic-anomaly lineations indicate asymmetrical spreading with about $14.1 \mathrm{~mm} / \mathrm{yr}$ to the west and $11.3 \mathrm{~mm} / \mathrm{yr}$ to the east. Possible duplication of anomalies to the west suggests that discrete eastward ridge jumps also may have occurred during the past 2 m.y. (Schulz et al., 1988).

\section{NORTHERN SPREADING SEGMENT OF THE MARK AREA}

\section{Setting}

The northernmost segment of the MARK area (Fig. 1) extends from the nodal basin at the Kane Transform southward to about $23^{\circ} 18^{\prime} \mathrm{N}$. The segment is defined on the basis of the extent of the prominent western median valley wall. An axial neovolcanic ridge runs the length of the segment and is the site of the Snake Pit hydrothermal field (Detrick, Honnorez, Bryan, Juteau, et al., 1988; ODP Site 649; Fig. 1). The southern end of the segment lies at the segment boundary zone that separates it from a more symmetrical spreading segment (Segment 2; Fig. 1) to the south.

The boundary zone between the two segments is a relatively wide transition zone (extending from $23^{\circ} 18^{\prime} \mathrm{N}$ to $23^{\circ} 05^{\prime} \mathrm{N}$ ) that corresponds with a probable offset of magnetic anomalies (Schulz et al., 


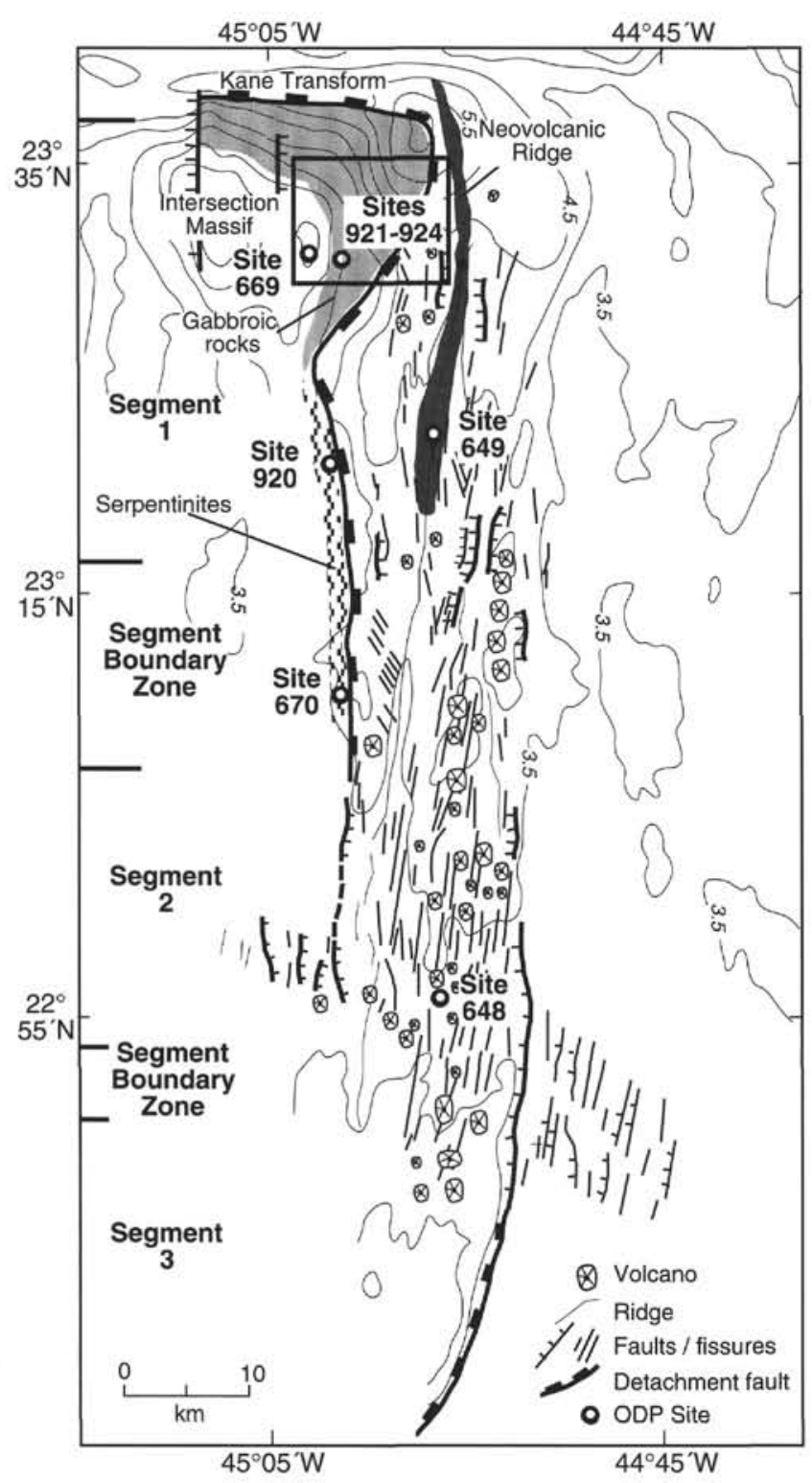

Figure 1. Generalized tectonic map of the MARK area, Mid-Atlantic Ridge at $22^{\circ}-24^{\circ} \mathrm{N}$ latitude. The box indicates the location of the gabbro outcrop area drilled at Sites 921-924 during Leg 153 and shown in more detail in Figure 2. Note that this area is part of a much more extensive belt of gabbroic rocks that crop out along the western median valley wall of the rift valley and along the southern wall of the Kane Transform. Gray pattern = gabbro outcrop area near the intersection with the Kane Transform. Zigzag pattern = serpentinite outcrop area inferred from submersible, side-scan sonar, and deep-towed camera data. Contours in kilometers below sea level. After Detrick, Honnorez, Bryan, Juteau, et al. (1988), Karson et al. (1987), Mével et al. (1991), and Cannat, Karson, Miller, et al. (1995). Ridge axis segments and boundaries are indicated along the left edge of the map.

1988), axial seismic discontinuity (Purdy and Detrick, 1986), and a marked change of rift-valley morphology and fault patterns (Karson et al., 1987; Kong et al., 1989). It has been interpreted as a zero-offset transform fault (Purdy and Detrick, 1986) or as an accommodation zone linking two segments with different spreading styles (Brown and Karson, 1988; Karson and Winters, 1992). Serpentinites crop out along the western median valley wall in the southern end of the northern segment (Site 920; Cannat, Karson, Miller, et al., 1995; Karson and Lawrence, this volume) and in the boundary zone (Site 670; De- trick, Honnorez, Bryan, Juteau, et al., 1988). Results of an off-axis swath mapping and gravity survey (Deplus et al., 1992; Gente et al, 1995) suggest that this accommodation zone or zero-offset transform can be traced into lithosphere of 7 to $9 \mathrm{Ma}$, as a bathymetric low with a coincident positive Residual Mantle Bouguer Anomaly (RMBA). Serpentinites dredged (Cannat et al., 1995) and drilled (Deep Sea Drilling Project Site 395; Melson et al., 1979) along this lineament support the interpretation that this is a band of relatively thin magmatic crust.

The northern segment is notable for the widespread exposures of gabbroic and ultramafic rocks that crop out along the western median valley wall (Karson and Dick, 1983; Karson et al., 1987; Mével et al., 1991). These rocks are interpreted as exposures of upper mantle and lower crust material that have been unroofed by extensional faulting and crustal thinning. Along-axis gravity studies in the northern ridge segment (Morris and Detrick, 1991) suggest that thin crust has been accreted there during at least the past 1 m.y.

The geology of the northern spreading segment in the MARK area and the ridge-transform intersection at the Kane Transform has been described in part in other earlier publications (Karson and Dick, 1983; Mével et al., 1991). Below, observations relevant to the setting of Sites 921-924 are reviewed and new data are reported. The dense data coverage with a wide array of survey techniques makes this area the most intensively studied tectonic window into the oceanic crust anywhere.

\section{Morphology}

SeaBeam bathymetric charts of the MARK area (Detrick et al., 1988) provide a comprehensive view of the morphology of this part of the Mid-Atlantic Ridge. They show that the axial valley floor of the spreading center deepens from about 3500 to over $6000 \mathrm{mbsl}$ as it descends into the closed-contour nodal basin at the Kane Transform intersection (Figs. 1,2). In profile, the rift valley is markedly asymmetrical: the western median valley wall has much greater relief $(>4000 \mathrm{~m})$ than the opposing eastern wall $(<1500 \mathrm{~m})$. The total relief and asymmetry of the rift valley increase as the transform is approached (Fig. 1). The inside lithosphere plate corner, defined by the intersection of the western Mid-Atlantic Ridge median valley wall and the southern wall of the Kane Transform, is marked by a relatively high, broad area that is about $20 \mathrm{~km}$ across and is referred to as an "inside corner high" (Severinghaus and Macdonald, 1988) or a ridgetransform "intersection massif" (Mével et al., 1991). Such features are common at ridge-transform intersections along slow-spreading ridges (Fox and Gallo, 1986).

The axial valley floor features a median ridge of young volcanic material extending from the north wall of the Kane Transform $40 \mathrm{~km}$ to the south, the entire length of the spreading segment. This neovolcanic ridge reaches a maximum height of $400 \mathrm{~m}$ and width of $\sim 4000$ $\mathrm{m}$ at $23^{\circ} 12^{\prime} \mathrm{N}$. The Snake Pit Hydrothermal Vent site is located on the summit of this edifice. At its northern end, the neovolcanic ridge tapers and has decreasing relief toward the nodal basin. It wraps around the eastern side of this depression and is reduced to a series of discontinuous conical peaks and rough topography across the trace of the transform. To the south, the neovolcanic ridge appears to terminate in the accommodation zone separating Segments 1 and 2 (Fig. 1).

The eastern valley wall has a stair-step morphology similar to that reported for many other segments of the Mid-Atlantic Ridge. The top of the wall is characterized by hook-shaped ridges (Fig. 1) that curve from north-south to more northwesterly orientations as they approach the Kane Fracture Zone (Pockalny et al., 1988).

The western median valley wall is exceptionally steep and rugged (Fig. 2). It has an average slope of $30^{\circ}$, but submersible dives show that it has an overall stair-step morphology with steep scarps up to $\sim 200 \mathrm{~m}$ high separated by terraces of a few tens of meters to $200 \mathrm{~m}$ wide (Karson and Dick, 1983; Mével et al., 1991). The terraces are 
Figure 2. SeaBeam bathymetric map of the area near Sites 921-924 (from survey by Detrick et al., 1988). Area corresponds to the box in Figures 1 and 3.

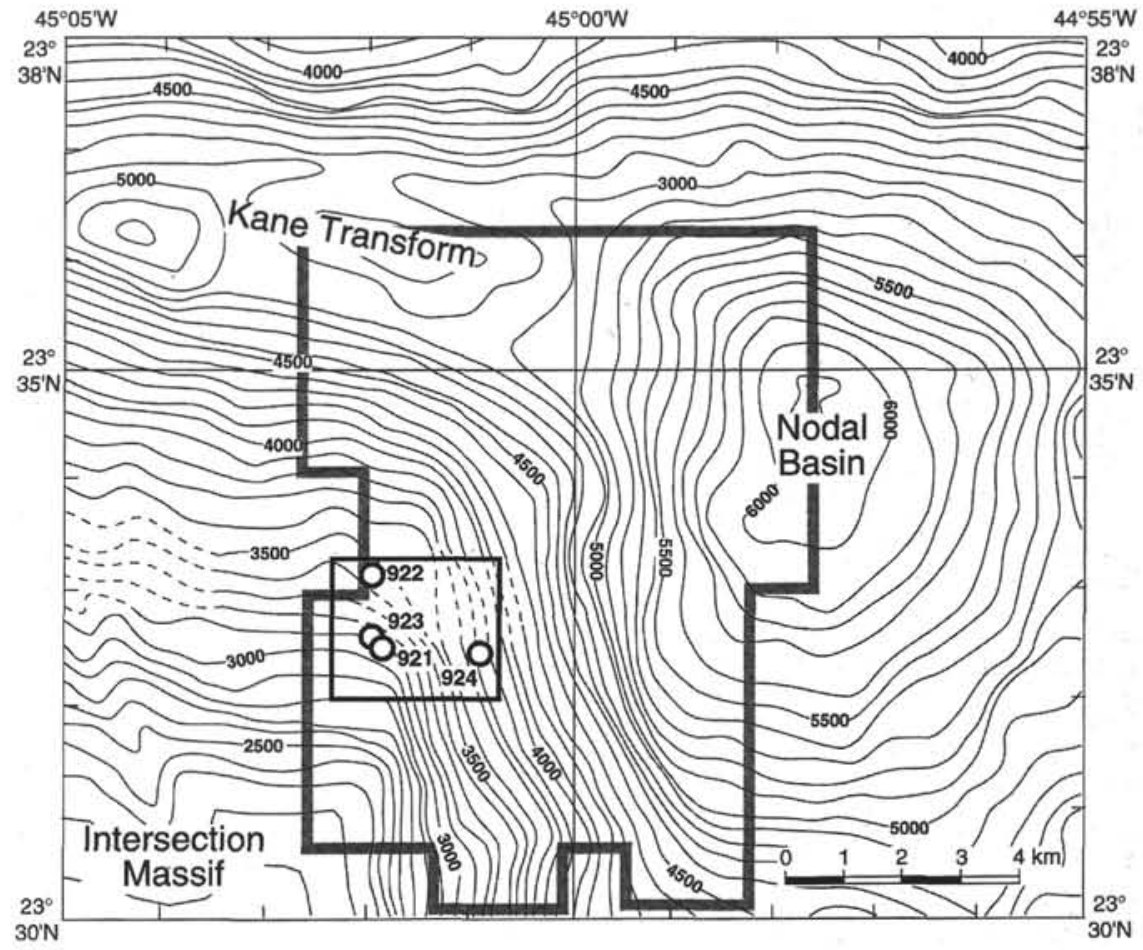

covered by pelagic ooze and scattered blocks of igneous rock, mostly in the form of debris slides. Fresh talus ramps lie at the base of the major scarps. The scarps themselves are extremely rugged in detail: northwest-trending scarps intersect less continuous east-west-trending walls, creating very jagged scarp edges composed of individual segments approximately $100 \mathrm{~m}$ in length. Massive promontories of plutonic rock are separated by swales that tend to be back-filled with rock debris and lesser pelagic ooze. The promontories and swales impart a broad-scale (wavelength several tens to $100 \mathrm{~m}$ ), downslopetrending, corrugation to the slope. The base of the slope tends to be dominated by debris-slide material locally including boulders $>10 \mathrm{~m}$ across. The crest of the slope is a broad shoulder with pelagic ooze increasing in thickness and continuity as the slope decreases. Above about $2500 \mathrm{mbsl}$, the only basement rocks exposed are in the form of widely spaced scarps of basaltic rubble material. These lineaments trend north to northwest and may be degraded fault-line scarps.

The north-facing slope of the intersection massif is the south wall of the Kane Transform valley; it has a very similar morphology to that of the rift valley wall. Near the ridge-transform intersection this slope has a very extensive, smooth blanket of pelagic ooze and compared with the eastern slope of the massif, has very little outcrop above $\sim 4000 \mathrm{mbsl}$ (Auzende et al., 1993a).

\section{Geology of the Intersection Massif}

The geology of the intersection massif and surrounding areas has been investigated with a wide array of research tools. On the eastern flank of the intersection massif (Figs. 2,3) the surface geology is constrained by 16 submersible dives concentrated on steep escarpments (Karson and Dick, 1983; Mével et al., 1991; Auzende et al., 1993a; J.A. Karson, S.D. Hurst, R.M. Lawrence, and SMARK Cruise Participants, unpubl. data); 11 deep-towed camera transects (ANGUS: Karson and Dick, 1983; deep-tow: Karson et al., 1992); SeaMARC I side-scan sonar in the rift valley floor (Kong et al., 1989); up- and down-looking side-scan sonar of the entire intersection area (Fig. 4; Karson et al., 1992; S.D. Hurst, D. Gao, J.A. Karson, J.R. Delaney, F.N. Spiess, unpubl. data), and numerous dredges (see Karson and Dick, 1983, for a summary). During Leg 153, 10 holes were drilled at four different sites on the western median valley wall. Sites 921924 provided the first subsurface samples of plutonic rocks in this area. During drilling operations, a number of drillstring video camera surveys were made in the vicinity of potential drill sites (Fig. 5).

\section{Median Valley Floor and Nodal Basin}

The geology of the median valley floor is similar to that described in the FAMOUS area (Macdonald and Luyendyk, 1977) and elsewhere on the Mid-Atlantic Ridge (Stakes et al., 1984; Eberhart et al., 1988; Auzende et al., 1993b; Bryan et al., 1994). In the northern segment of the MARK area, the floor of the median valley is a hummocky pillow lava terrain cut by numerous minor faults and fissures (Fig. 6A). Pelagic carbonate ooze up to about $1 \mathrm{~m}$ thick partially covers the lavas. The youngest basaltic lavas are confined to the median neovolcanic ridge (Karson et al., 1987; Brown and Karson, 1988; Gente et al., 1991). Based on large-scale terraces, sediment cover, and degree of fracturing, there appears to be a bilaterally symmetric pattern of lava surfaces on the median valley floor in which the youngest lavas are centered on the neovolcanic ridge and progressively older lavas are located toward the edges of the median valley (Gente et al., 1991). As it descends into the nodal basin, the floor of the median valley is covered by a more or less continuous blanket of pelagic ooze. This is interrupted by isolated boulders and debris slides derived from surrounding scarps. Extensive outcrops, continuous with those of the western median valley wall, occur across the western half of the nodal basin.

\section{Eastern Median Valley Wall}

The eastern median valley wall is typical of block-faulted MidAtlantic Ridge segments elsewhere (Macdonald and Luyendyk, 1977; Crane and Ballard, 1981; Stakes et al., 1984; Karson and Rona, 1990) and has a total relief of about $1500 \mathrm{~m}$. It is characterized by block-faulted pillow lavas with a generally increasing sediment cover away from the spreading axis. The average slope of the wall is less than $20^{\circ}$, but in detail is comprised of a series of fault scarps some tens of meters high separated by relatively flat terraces a few tens to 


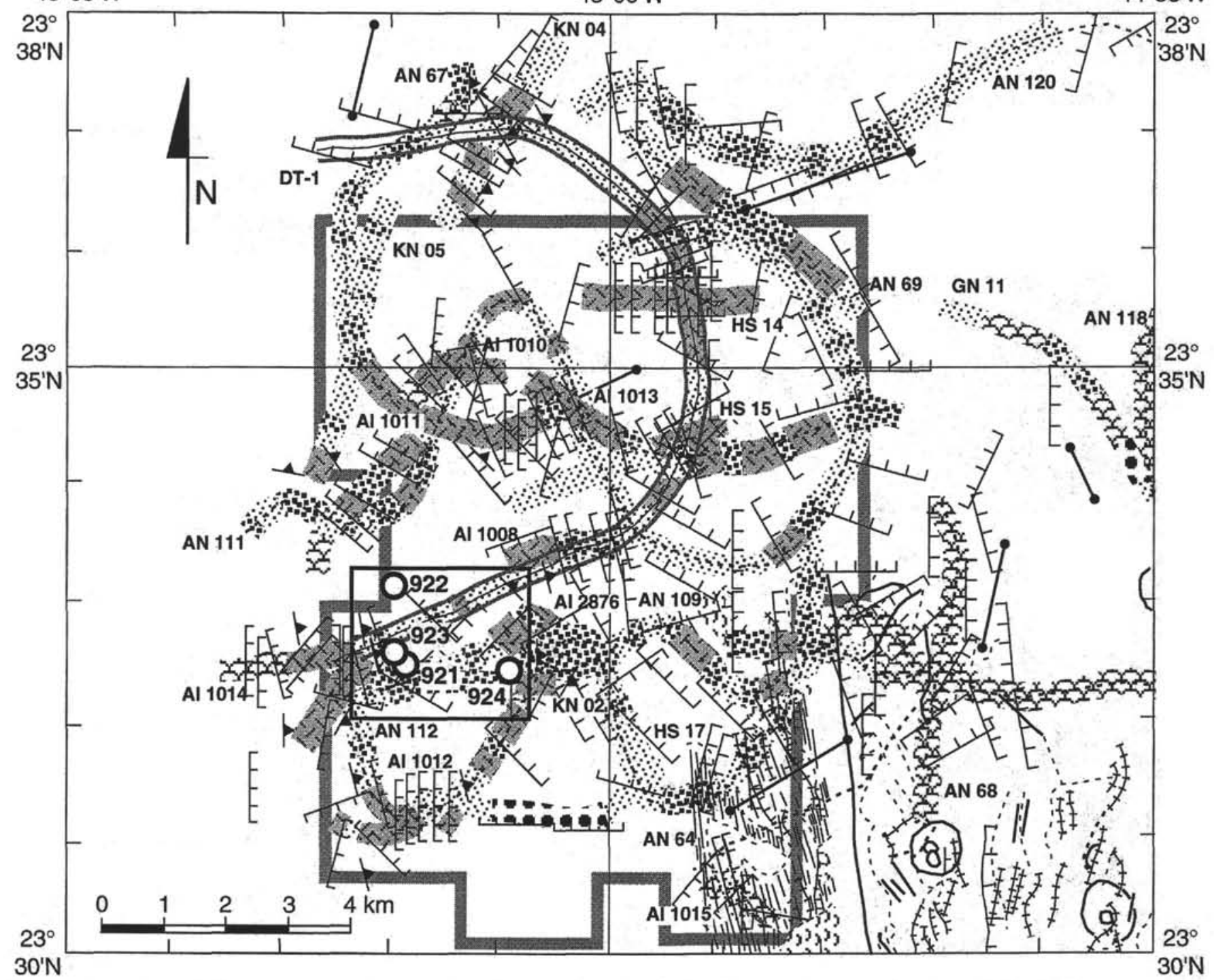

\section{Geology}

ooze > blocks
blocks > ooze
fresh talus
bedded chalks
basaltic lavas
gabbroic rocks
fault scarps
schistosity

Sonar Reflectors

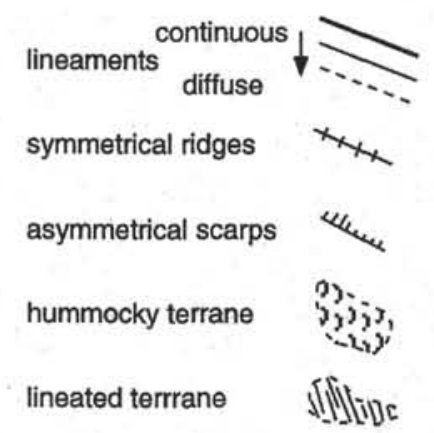

Survey symbols

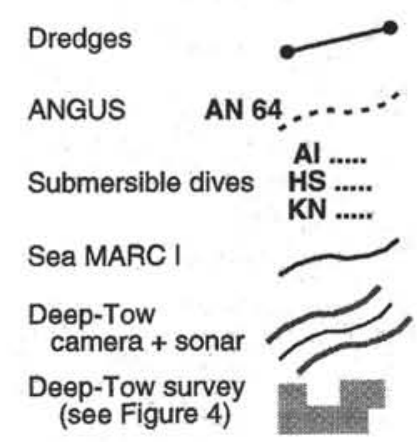

Figure 3. Geology in the vicinity of Sites 921-924. Data from SeaBeam bathymetry (Detrick et al., 1988); SeaMARC I side-scan sonar (Kong et al., 1989); ANGUS and deep-tow camera runs (AN; Karson and Dick, 1983; DT; Karson et al., 1992); Alvin dives (AL; Karson and Dick, 1983; J.A. Karson, S.D. Hurst, R.M. Lawrence, and SMARK Cruise Participants, unpubl. data, 1995); Nautile dives (HS and KN; Mével et al., 1991; Auzende et al., 1993a); and dredges (see Karson and Dick, 1983, for a summary). The dashed box shows the area covered by the Scripps Institution of Oceanography (SIO) deep-tow up- and downlooking side-scan sonar (Fig. 4; Karson et al., 1992). The box around the drill sites shows the extent of an ODP video camera (VIT) survey (see Fig. 5). Note the blank area in the near field along the SeaMARC I path along the eastern edge of the map area. The deep-tow camera run also has side-scan sonar out to a range of $\sim 200 \mathrm{~m}$ approximated by the gray lines bordering the track. 


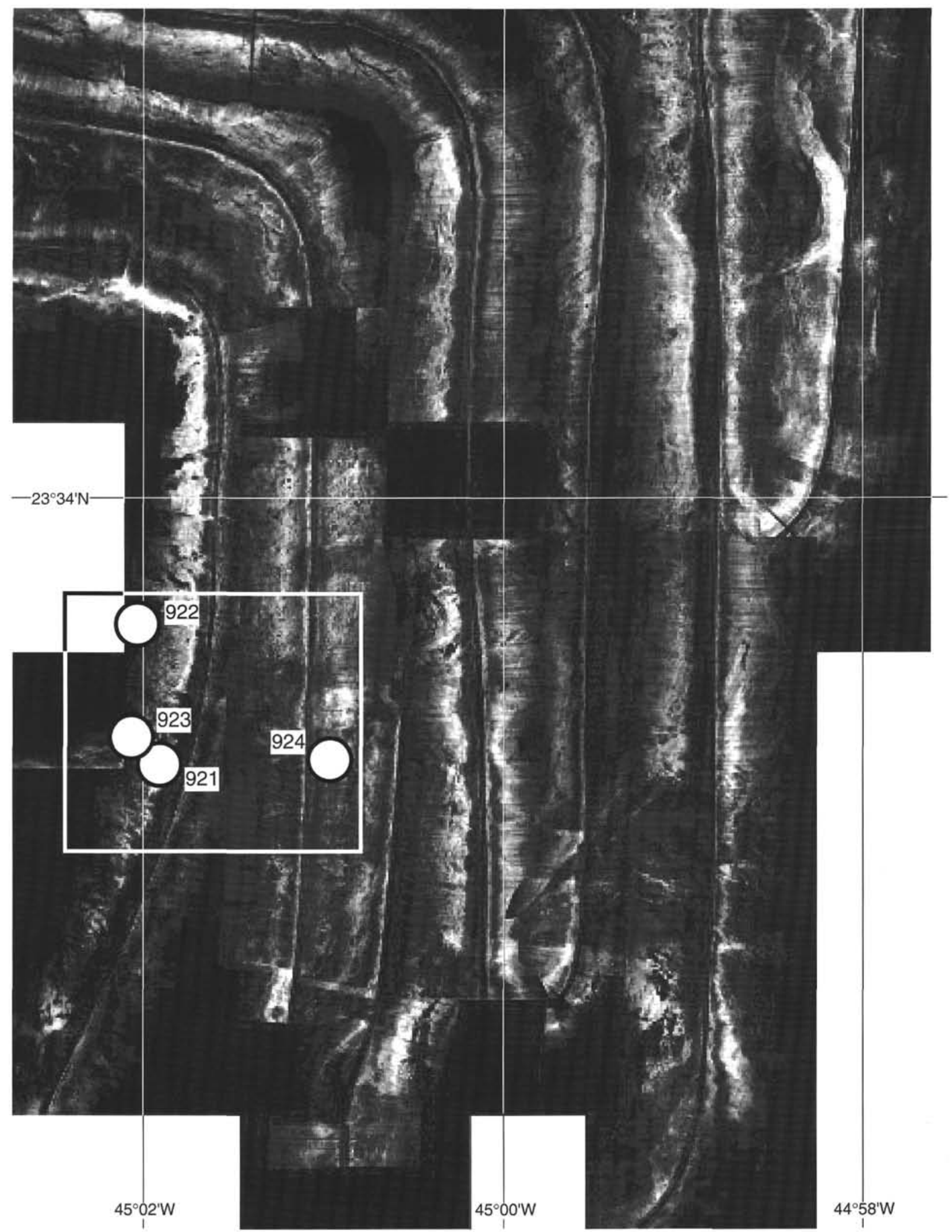

Figure 4. Up- and down-looking side-scan sonar mosaic produced from data collected using the SIO deep-tow camera. The mosaic shows only the part of the survey area around the drill sites (from S.D. Hurst, D. Gao, J.A. Karson, J.R. Delaney, and F.N. Spiess, unpubl. data). 


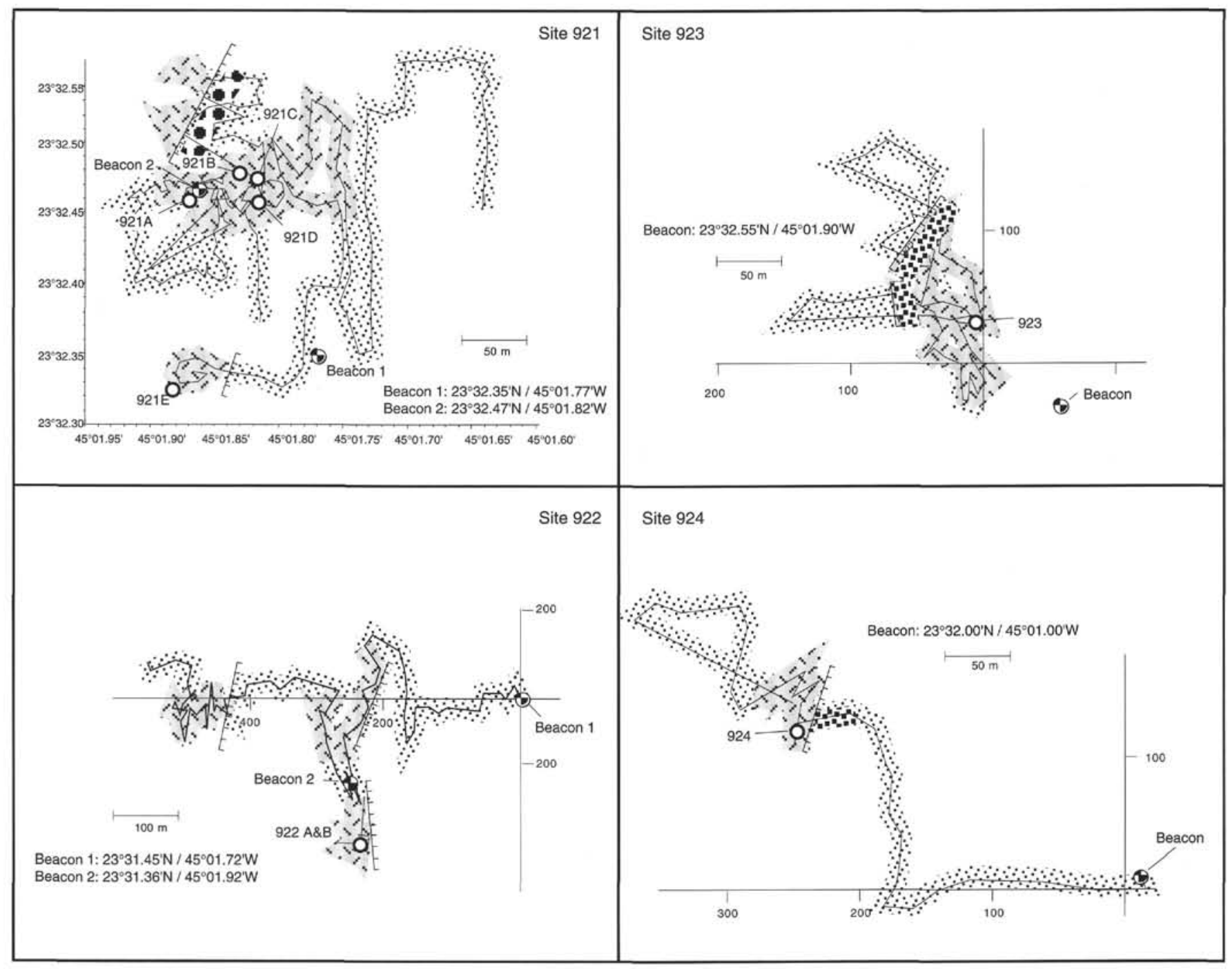

Figure 5. Summary of the geology around Sites 921-924 from ODP video camera (VIT) survey conducted during Leg 153 (see Fig. 3 for symbols).

a hundred meters wide. Although the sediment distribution is very uneven in this area, with bare basaltic rocks exposed on some peaks and ridges, there is no evidence of active or young volcanism. Ridges of basaltic material near the crest of the wall, corresponding to the "hook-shaped ridges" of Pockalny et al. (1988), have relatively fresh, lightly sedimented pillow lavas (Karson and Dick, 1983).

\section{Western Median Valley Wall}

Compared with the eastern wall, the western median valley wall is as different geologically as it is morphologically. Rising more than $4 \mathrm{~km}$ from the median valley floor, it is an extensive exposure of middle to lower crustal mafic plutonic rocks exposed by extreme faulting (Fig. 3). These exposures have been sampled by dredges (Miyashiro et al., 1970, 1971), Alvin dives (Karson and Dick, 1983; J.A. Karson, S.D. Hurst, R.M. Lawrence, and SMARK Cruise Participants, unpubl. data), and Nautile dives (Mével et al., 1991; Auzende et al., 1993a). Submersible observations have documented extensive outcrops of variably deformed and metamorphosed gabbro, metagabbro, metabasalt, and metadiabase, and lesser serpentinized peridotite. Outcrops of plutonic rocks extend from the median valley and nodal basin floor at $>6000 \mathrm{mbsl}$ upslope to at least $2500 \mathrm{mbsl}$, a lateral distance of 8-10 km (Fig. 3). Preliminary analysis of side-scan sonar backscatter patterns suggests that this terrain extends well into the floor of the nodal basin and that it is directly overlain by young, highly reflective basalts of the neovolcanic ridge (Karson et al., 1992).

The outcrops of gabbroic rocks on the western median valley wall are marked by moderately east-northeast-dipping faults and shear zones (Fig. 6B) that are parallel to the overall slope of the wall, about $30^{\circ}$, defining a nearly continuous "dip-slope" (Fig. 6C). Some fault surfaces can be followed for several hundreds of meters upslope and may correspond to major detachment faults (Dick et al., 1981; Karson and Dick, 1983; Karson, 1990; Mével et al., 1991). In some places, diabase dikes cut the gabbroic rocks (Fig. 6D), but they are not obviously deformed by the faults and shear zones (J.A. Karson, S.D. Hurst, R.M. Lawrence, and SMARK Cruise Participants, unpubl. data).

The east-northeast-dipping faults and shear zones of the eastern face of the massif may be kinematically linked to similar features that dip to the north and northeast along the northern, transform-parallel wall. On both edges of the intersection massif, the gently dipping fault zones are commonly cut by higher angle faults that impart the stepped morphology to the edges of the massif. Faults on the eastern side are normal faults with down-dip plunging slickensides and striae, whereas faults with moderately to gently plunging striae occur along the transform valley wall. The low-angle fault zones are con- 


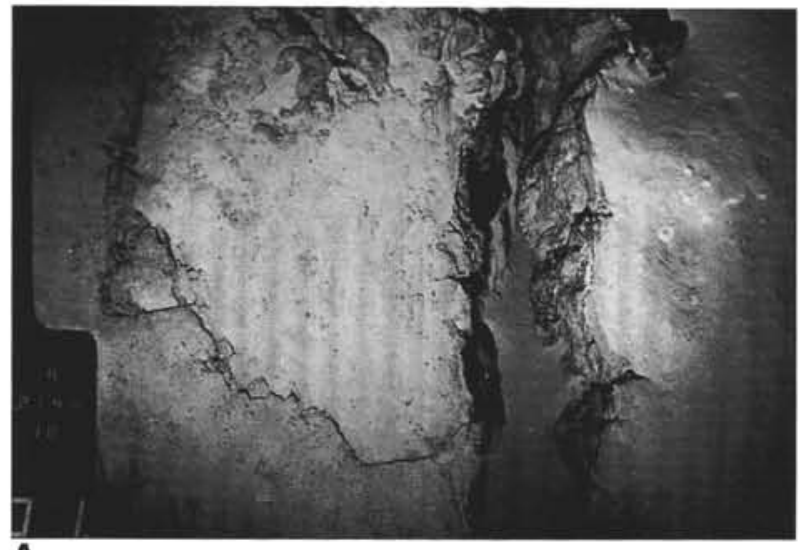

A

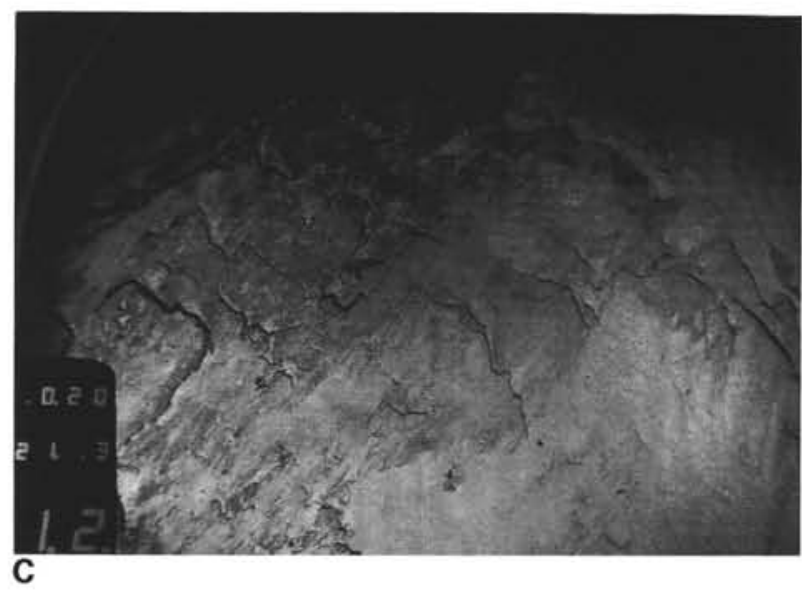

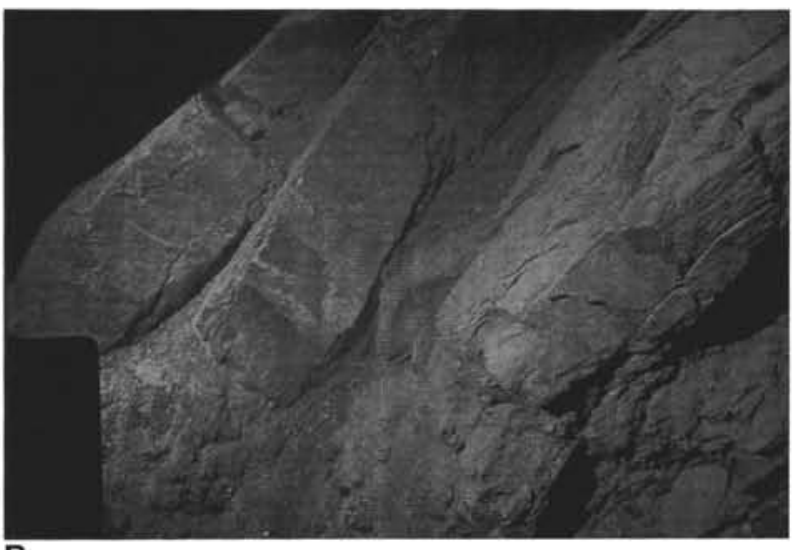

B

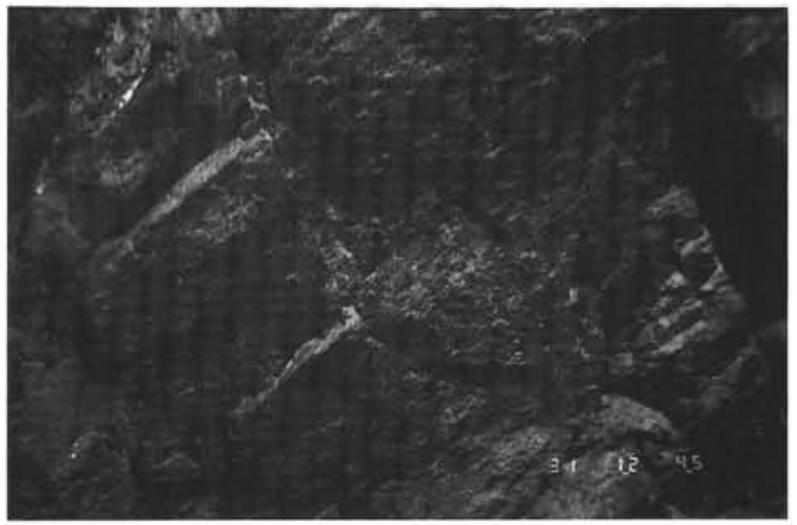

D

Figure 6. Outcrop photographs from the area surrounding Sites $921-924$ (see Fig. 2 for locations). A. Vertical fissure about $1.5 \mathrm{~m}$ wide, cutting a basaltic lava flow on the median valley floor between the neovolcanic ridge and the western median valley wall; vertical-incident ANGUS photograph, ANGUS 64. B. Slabs of massive gabbroic rock separated by shear zones with anastomosing cataclastic fabrics, western median valley wall $\sim 4760 \mathrm{~m}$; side viewport photograph from Nautile, HS-14. C. Fault dip-slope surface in massive gabbroic rock. Outcrop slopes moderately down toward the top of the photograph; vertical-incident ANGUS photograph, ANGUS 112. D. North-dipping dike cutting gabbroic rocks near Site 924, $3232 \mathrm{~m}$; side viewport photograph from Alvin, AL 2577.

sidered to represent an uplifted and exhumed detachment surface (rift valley wall of the massif) and lateral ramp (transform wall) in a major crustal detachment system (Mutter and Karson, 1992). These surfaces may correlate with gently dipping intracrustal reflectors seen in seismic profiles of slow-spreading crust (Mutter and Karson, 1992).

Outcrops above about $2500 \mathrm{~m}$ depth are mostly ridges of fractured pillow basalts and basaltic breccias up to a few meters high. More continuous outcrops of approximately flat-lying basaltic pillow lavas occur on the western flank of the massif (Mével et al., 1991). The basaltic rocks are interpreted as upper crustal material that formed above the plutonic rocks exposed on the walls of the massif (Karson and Dick, 1983; Mével et al., 1991). The contact between the basaltic rocks and mafic plutonic rocks that crop out at deeper levels has not been observed. Maximum depths of basaltic outcrops around the massif suggest that this contact dips gently $\left(\sim 10^{\circ}-15^{\circ}\right)$ to the west. Given the lack of available constraints, the contact could be an igneous construction above the plutonic suite, a nonconformity over a faulted surface in plutonic rocks, or a low-angle fault.

It is noteworthy that even though diabases have been dredged and sampled by submersibles, no sheeted-dike complex has been found between the gabbroic and extrusive basaltic units. If a sheeted-dike unit is present, outcrop distributions on the eastern edge of the massif restrict its maximum thickness to about $200 \mathrm{~m}$.

The gabbroic samples dredged and collected during submersible dives from the intersection massif include variably deformed and metamorphosed olivine gabbro to gabbronorite as well as more highly evolved ferrogabbro to trondhjemite (Karson and Dick, 1983;
Mével et al., 1991; Marion et al., 1991; Marion, 1993). Whereas igneous textures including coarse-grained cumulates are common, overprinting by later deformation fabrics is nearly ubiquitous. Ductile shear zones and penetrative foliations show extensive crystalplastic deformation with strongly recrystallized plagioclase. Brittle deformation structures are evident in nearly all samples and range from widely spaced fractures and veins to pervasive cataclastic fabrics. Samples with pervasive mylonitic to ultramylonitic textures (Fig. 7) are also common (Karson and Dick, 1983; Mével et al., 1991).

Metamorphic assemblages indicate alteration by both high-temperature magmatic fluids and seawater (Kelley and Delaney, 1987; Kelley, this volume). Some samples have igneous mineral assemblages with crystal-plastic deformation fabrics suggesting low-pressure granulite facies conditions. Foliated metagabbros more typically have amphibolite facies assemblages. Nearly all samples are overprinted by at least local greenschist to sub-greenschist facies assemblages (Karson and Dick, 1983; Mével et al., 1991). Details of these metamorphic rocks are described in several publications (Delaney et al., 1987; Marion et al., 1991; Marion, 1993; Kelley et al., 1993; Gillis et al., 1993),

Fluid inclusion microanalyses suggest pressures of entrapment of $>100 \mathrm{MPa}$ for high-temperature inclusions (Kelley and Delaney, 1987). These pressures correspond to mid-crustal depths, even allowing for hydrostatic pressures from water depths in the median valley. These data suggest both significant unroofing and uplift of these metabasites (Kelley and Delaney, 1987). In addition, textural and fluid 


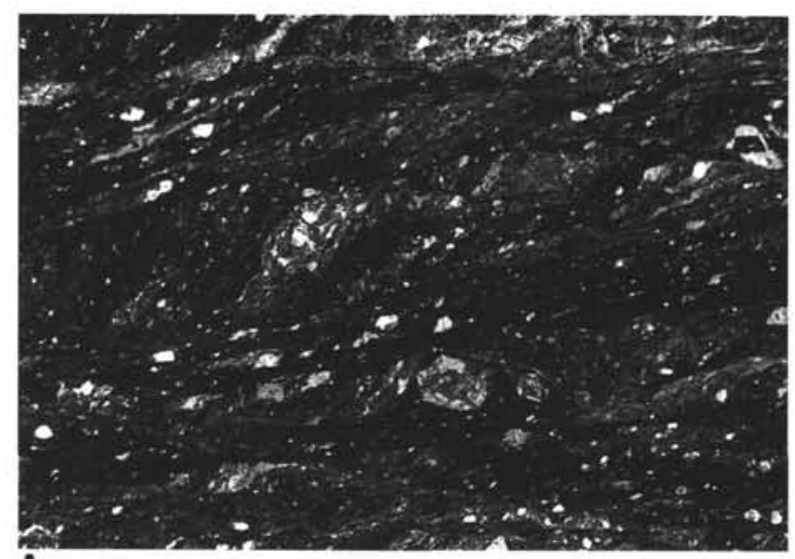

A

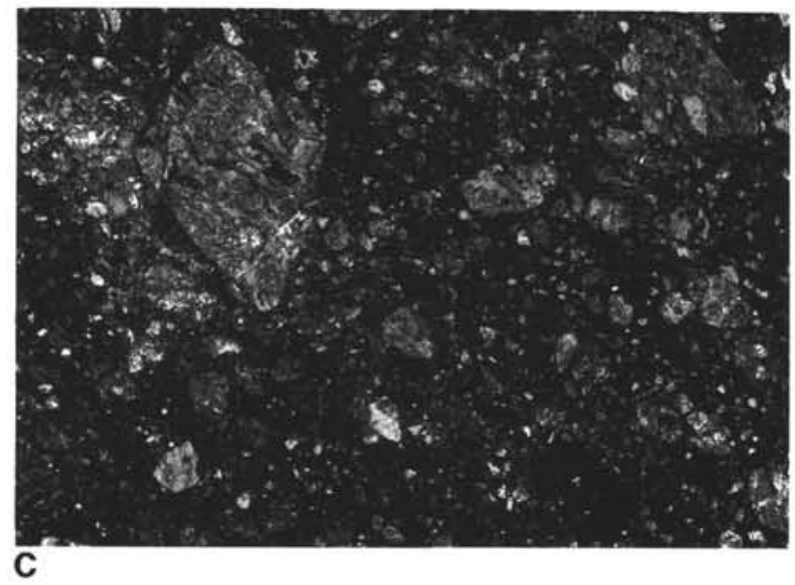

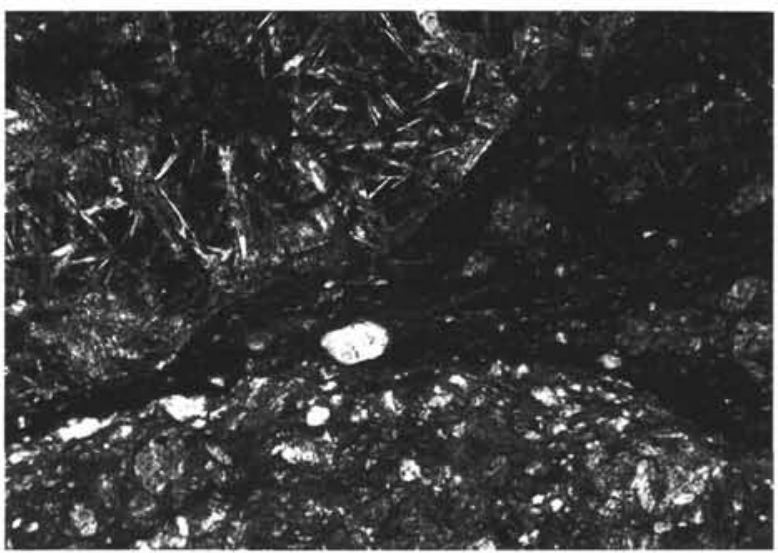

B

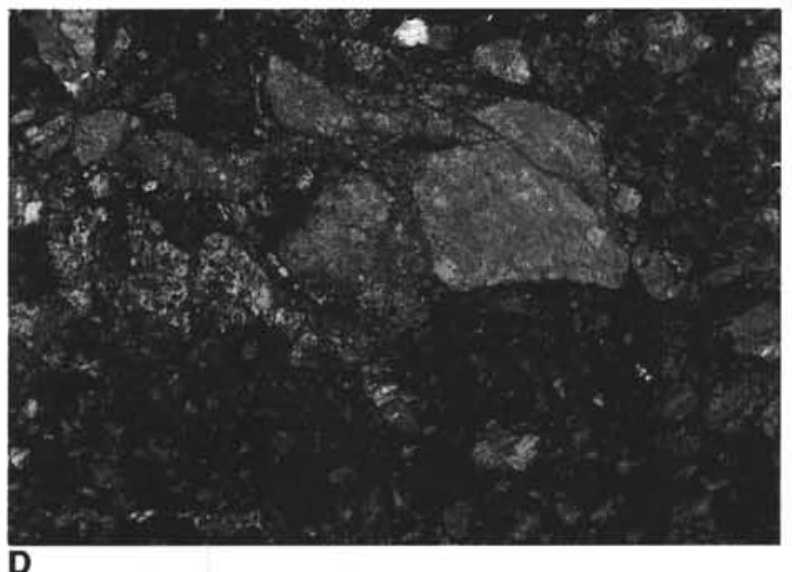

Figure 7. Photomicrographs of gabbroic rocks near Sites 921-924. A. Mylonitic metabasite with asymmetric porphyroclasts and lensoid domains of metagabbro to metadiabase; Alvin dive 1010, sample 5, from gently dipping detachment surface. B. Detail of Alvin sample 1010-5 showing mylonitic fabric in shear zones separating clasts of cataclasite and metabasalt with surviving acicular plagioclase laths. C. Cataclasite to fault gouge in metagabbro from low-angle detachment surface; Alvin dive 1014, sample 9. D. Cataclasite with metagabbro clasts from detachment surface; Alvin dive 1011, sample 3 . Long dimension of field of view is $4 \mathrm{~mm}$.

inclusion studies of hydrothermal breccias suggest that elevated pore-fluid pressures, approaching lithostatic stress, may have existed at least intermittently along major fault zones (Delaney et al., 1987).

In summary, the Mid-Atlantic Ridge spreading segment just south of the Kane Transform is highly asymmetrical in its morphology, distribution of rock types, and structures. The rift axis and eastern wall appear to be typical of many other areas of the Mid-Atlantic Ridge; however, the western wall that flanks a broad, high-relief massif is significantly different. This massif consists of uplifted and exhumed mid-crustal to lower crustal gabbroic and related rocks that probably initially crystallized beneath the spreading axis. High-temperature deformation fabrics are overprinted by progressively lower temperature metamorphic assemblages and more brittle deformation structures. Low-angle normal and strike-slip faults that bound the eastern and northern flanks of the massif, respectively, appear to be kinematically linked segments of a major detachment system. This highly stretched and thinned middle to lower crustal exposure may be regarded as an oceanic core complex.

\section{DRILLING GABBROIC ROCKS}

Sites 921-924 are located on the upper eastern slopes of the western median valley wall (Cannat, Karson, Miller, et al., 1995) in an area of particularly dense coverage by previous studies (Fig. 3). Each hole at these sites was drilled directly on top, or just a few meters above, gently to moderately sloping outcrops of slabby to schistose rocks, interpreted as dip-slopes on fault surfaces and shear zones in otherwise massive material (Fig. 5). Holes drilled at Sites 921-924 all lie within about $2 \mathrm{~km}$ of one another and Sites 921 and 923 are only about $200 \mathrm{~m}$ apart (Fig. 2). Site 922 lies approximately along an isochron line to the south of Sites 921 and 923 . Site 924 lies approximately along a spreading flow-line $\sim 1800 \mathrm{~m}$ to the east of Sites 921 and 923 . Variations in igneous, deformational, and metamorphic features in the rocks recovered from these holes may therefore reflect both along-axis and temporal variability in the processes that create and modify middle to lower crustal rocks. Site 924 is closer to the Mid-Atlantic Ridge axis; therefore, if the simplest, symmetrical spreading history and regional half-rate is assumed, the rocks recovered from this site might be as much as 100,000 yr younger than those at the other sites.

The 10 holes drilled at Sites 921-924 penetrated to depths ranging from 14 to 82 meters below seafloor (mbsf), with cumulative recovery rates of $11 \%$ to $74 \%$. The rocks recovered display a remarkably wide range of igneous, metamorphic, and deformational features (Cannat, Karson, Miller, et al., 1995), reflecting a very complex geologic history for the crust of the detachment footwall. The dominant rock types are gabbro and olivine gabbro. Subordinate volumes of troctolite, oxide gabbro, and leucocratic veins also occur. These rocks feature a variety of cumulate textures. Magmatic layering is defined by variations in grain size, modal mineralogy, and rarely both, on the scale of $1 \mathrm{~cm}$ to a few meters. In some places, the attitude of 
layering varies significantly within the cores, locally changing from subhorizontal to subvertical over vertical intervals of as little as about $1 \mathrm{~m}$ in continuous pieces of core (Cannat, Karson, Miller, et al., 1995). Cycles of relatively primitive to somewhat more evolved rock types may indicate recurrent evolutionary magmatic sequences; such cycles have been identified in both layered and nonlayered intervals (Stevens, this volume).

Other minor lithologies include oxide gabbro, commonly associated with zones of high ductile shear strain and altered felsic veins, some of which are quartz-bearing. The leucocratic veins, and zircon and apatite-bearing oxide gabbro, are likely to represent crystallization products of highly evolved melts.

The gabbroic rocks recovered display a wide range of crystalplastic to cataclastic deformation fabrics (Cannat, Karson, Miller, et al., 1995; Agar et al., this volume; Fletcher, Ceuleneer, et al., this volume). Crystal-plastic deformation is commonly concentrated in centimeter- to decimeter-scale shear zones in which primary minerals have undergone extreme grain-size reduction as a result of dynamic recrystallization. These shear zones commonly have down-dip stretching lineations and display kinematic indicators, suggesting normal displacements. The dips of these shear zones are variable, but commonly moderately to steeply dipping. Dip directions are not constrained by presently available data.

In contrast to the widespread fault surfaces exposed in outcrops, brittle deformation features are comparatively rare in the cores; a small number of cataclastic zones, only a few centimeters wide, were recovered. Veins and isolated fractures, however, are widespread in the cores (Dilek, Kempton, et al., this volume). Some of the most extensive cataclastic shear zones occur in the upper sections of Holes 921B, 921C, and 923A. These brittle shear zones are typically a few centimeters to decimeters thick and contain fractured, angular clasts of gabbroic material in a fine-grained matrix of cataclasite to gouge (Fig. 8). Individual clasts commonly display evidence of high-temperature mineralogy and crystal-plastic deformation overprinted by the low-grade cataclastic matrix, suggesting that faults exploited preexisting ductile shear zones. The cataclastic shear zones appear to have gently dipping orientations, and they are likely to be associated with the east-dipping fault surfaces seen in the surrounding outcrops by the ODP video survey (Fig. 5) and submersible dives (Fig. 3). Apart from these cataclastic shear zones, very few deformation structures recovered in the drill cores have low-angle orientations or are likely to be kinematically related to the low-angle fault zones and foliations so widely developed at the surface.

Remanent magnetizations of the gabbros are complex and have multiple components, which indicate that both normal and reversed polarity material are present (Cannat, Karson, Miller, et al., 1995). Reversely polarized material suggests a minimum age of $0.7-0.9 \mathrm{Ma}$ for these rocks, which is roughly consistent with the crustal age calculated, using spreading rates from regional magnetic anomaly studies (Purdy et al., 1979; Schulz et al., 1988).

In summary, the gabbroic rocks recovered from Sites 921 to 924 display large variations in composition, grain size, texture, degree of deformation, and extent of alteration that could not be easily inferred from surface samples. The textural variations, commonly occurring
A

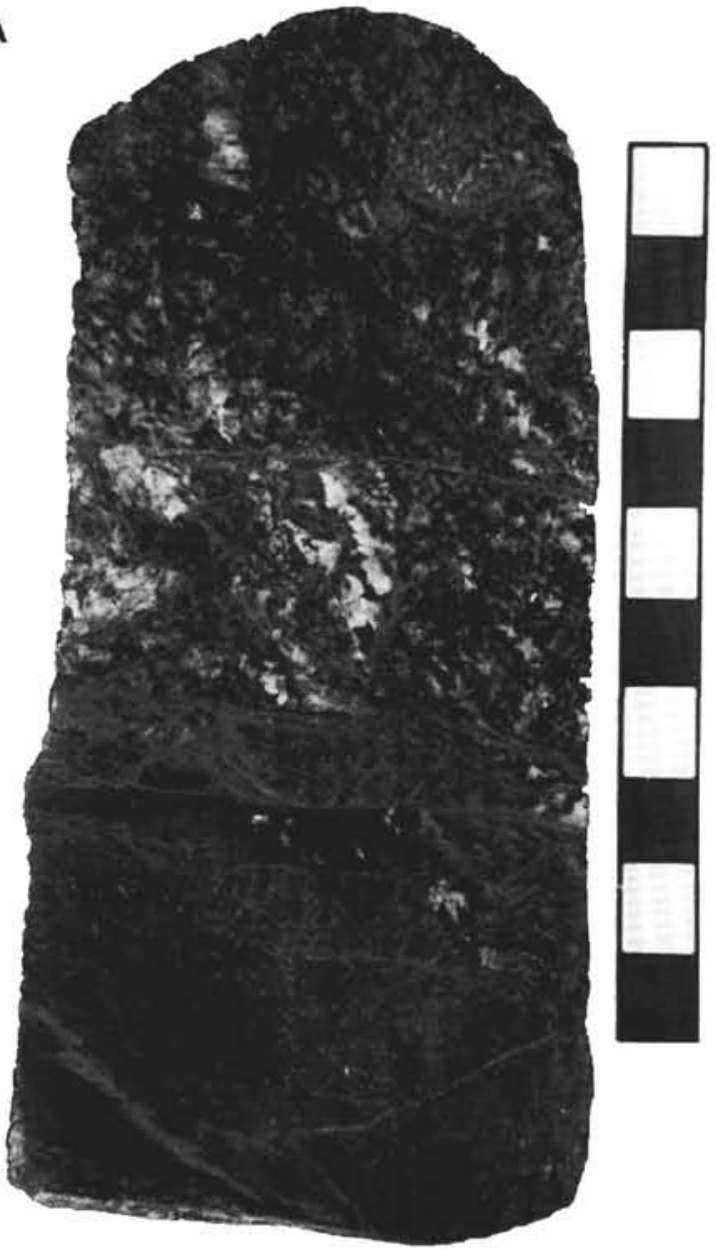

B

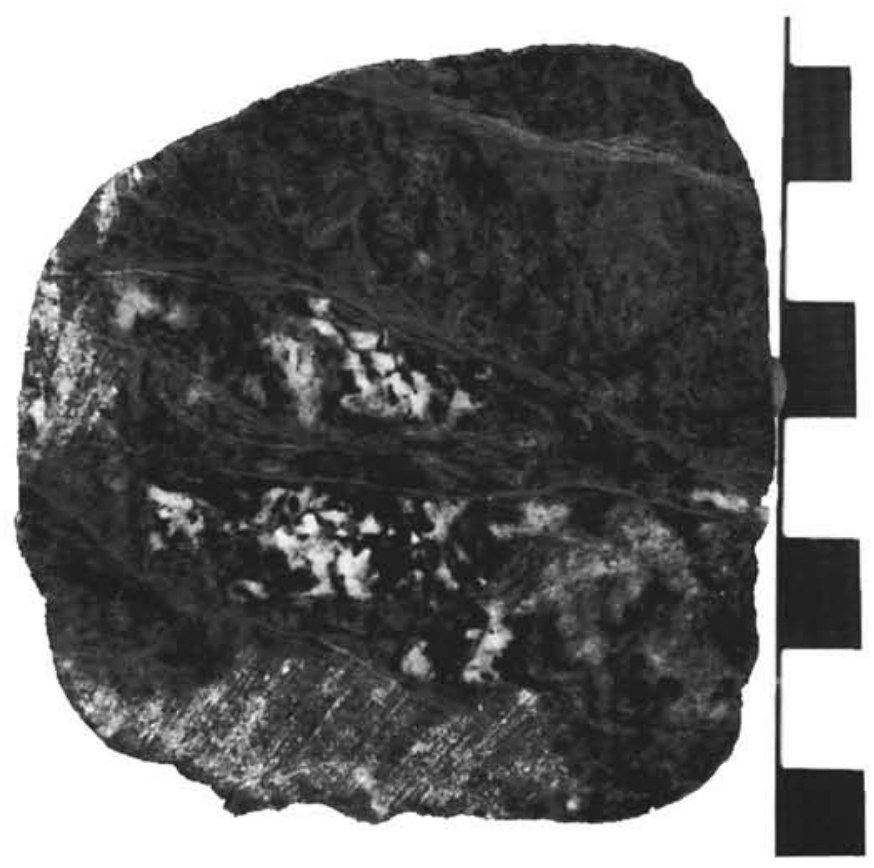

Figure 8. Core photographs from Sites 921 to 924 . A. Coarse-grained metagabbro grades downward through spaced shear zones into dark cataclasite (Sample 153-921B-1W-1, Piece 12, 91-103 cm). B. Slices of coarse-grained metagabbro separated by anastomosing cataclastic shear zones (Sample 153-921B-1W-1, Piece 4, 20-25 cm). Centimeter scale shown on both A and B. 
over lengths of a few centimeters to tens of centimeters, suggest crystallization in an environment characterized by high thermal gradients and syn- to postmagmatic deformation. Generally, the rocks include meter-scale layers of gabbro and olivine gabbro, with lesser troctolite and iron-titanium oxide gabbro. Meter-scale diabase dikes with chilled margins are also present. Alteration of the igneous mineralogy is generally low and very nonuniform at the decimeter to meter scale. Highly altered sections of the core are rare, and are typically restricted to narrow mylonitic and cataclastic zones, or to the margins of crosscutting felsic veins. Paleomagnetic properties of the rocks help constrain their age and the overall history of spreading. These results add substantially to the outcrop information from surface studies and provide a three-dimensional view of the crust of the detachment footwall.

\section{DISCUSSION}

\section{Integrated Approaches to Studying Volumes of Oceanic Crust}

Drilling during Leg 153 and studies of the surface geology using manned submersibles have provided important complementary data sets relevant to the interpretation of exposures of mafic plutonic rocks of the intersection massif near the Kane Transform. The integrated results of these investigations provide a compelling case for the combined use of these perspectives.

\section{Submersibles}

Submersible surveys can provide maps of rock units and surface structures such as fault scarps. They can constrain the three-dimensional geometry of deformation structures exposed on major escarpments and accurately quantify the orientations and dimensions of fault scarps and other surface features such as lava flows, dikes, and mass-wasting features. These observational data are probably somewhat biased in that they are typically limited to very steep intervals that are almost certainly produced by active or recent tectonic processes. This raises the old question of how representative samples collected may be of the regional-scale geology of oceanic rock units. In any case, rock samples with dimensions of a few tens of centimeters are commonly the maximum size collected. A significant advantage of samples from submersibles is that fully oriented samples for paleomagnetic and microstructural studies can be obtained; however, sampling and observations are limited by the lateral and vertical dimensions of these scarps. Whereas the lateral continuity of scarps may be kilometers in length, continuous vertical intervals exposed by single fault scarps are generally limited to less than $100 \mathrm{~m}$.

\section{Drilling}

Drilling has a different set of strengths and limitations. At present, oceanic hard-rock drilling is limited to a few hundred meters and then only in very coherent rock formations. Present drilling techniques have not proven capable of efficient penetration and recovery of highly jointed or fractured basaltic rocks or other young crustal material. However, even with limited penetration depths, holes can be located away from obvious tectonically produced escarpments to sample material that may be systematically missed by submersible studies. Sample dimensions are limited to the core diameter of a few centimeters, but nearly continuous core lengths can be as much as a few meters. Where recovery is very good, nearly continuous vertical variations can be viewed on the scale of several meters to a few hundred meters (maximum depths penetrated to date). Unfortunately, azimuthal orientations are not constrained at present and will be difficult to obtain. Arrays of holes in a given area can help constrain lateral variations in structure and composition that are essential to evaluating the processes that create volumes of oceanic crust and upper mantle rocks.

\section{Integrated Results of Drilling and Submersible Studies}

The different perspectives on the nature of the oceanic crust that come from these different approaches help to explain some of the apparent contradictory results of the investigations on the western median valley wall of the MARK area, but they also raise some questions for future studies.

Submersible and dredge samples from the area commonly included ferrogabbros and oxide gabbros and suggested that these materials are abundant in the slow-spreading crust. Although this finding is not entirely excluded by the drilling results, these rock types are relatively rare in the material cored at Sites 921-924. Gabbros and olivine gabbros are the dominant rock types in the cores, and ferrogabbros and oxide gabbros are concentrated along shear zones. Consideration of the submersible and drilling results suggests that the surface studies preferentially sampled tectonic escarpments localized along shear zones and that major compositional variations occur over a length scale of approximately $2 \mathrm{~km}$, the distance between the holes.

Submersible studies in the area show extensive dip-slope exposures of major low-angle fault zones, parallel shear zones, and foliated intervals. Rocks collected from these shear zones show intense deformation with cataclastic fabrics overprinting crystal-plastic fabrics. Mylonites and cataclasites document very large down-dip shear displacements on these surfaces. Thus, it was anticipated that a major shear zone would be encountered near the tops of the cores followed by less deformed material deeper in the footwall. Although material recovered from the cores did not show a discrete fault or shear zone near the surface, the shallowest portions of a number of cores have abundant cataclastic rocks. However, recovery was very poor in the upper few meters of most cores. It is possible that the surficial fault zone was not recovered, just as we suspect many other faulted intervals were systematically excluded in the process of drilling. During recent Alvin dives on major fault zones in Segment 3 of the MARK area (Fig. 1), layers of very friable cataclasite and gouge at least $1 \mathrm{~m}$ thick were found just below pelagic cover. It is likely that this material would not be recovered by conventional rotary drilling techniques. The mapped fault surface may also have been removed locally by mass wasting or incision of the fault zone by relatively late fault strands. Drilling alone would not have revealed this major feature.

Discrete high-temperature shear zones ranging from amphibolite facies shear zones to mafic mylonites were recovered by submersibles prior to drilling. Drilling provided excellent samples of this material, which can be oriented with respect to vertical for quantitative microstructural and metamorphic studies. Furthermore, the shear zones can be viewed in the context of surrounding rocks from which they were derived and with which they generally have gradational contacts so that progressive textural and compositional changes can be documented. Collecting geological contacts in submersible samples, especially those of a gradational character, would be very fortuitous.

Most of the submersible and dredge samples of gabbroic rocks show some signs of weathering and low-temperature alteration along fractures. This is pervasive in many fault rocks. In the drilled samples, igneous textures in many intervals are very fresh and undisturbed by these effects. In the drill cores, many fault rocks and intervals of rocks with nearly pervasive, but weak, ductile deformation fabrics show well-preserved evidence of high-temperature deformation ranging from magmatic to transitional granulite facies conditions. The high-temperature fabrics are rare in the surface samples, which are typically strongly overprinted by later brittle, low-temperature features. Low-temperature, cataclastic deformation is much less common in the drill cores than in the submersible samples.

These observations raise some important issues that are relevant to the current understanding of the plutonic foundation of oceanic crust. Sampling biases appear to be inherent to both surface and drilling studies. It appears that the low-temperature/brittle features are more characteristic of the steep, faulted areas sampled by submersibles than the crust beneath intervening terraces. Intervals of intensely 
fractured material along fault zones may be systematically excluded by current drilling and core recovery techniques. It is not clear from available sampling how widespread the low-strain, high-temperature deformation fabrics might be and how they are related to crustal accretion. These ambiguities can probably only be resolved with improved core recovery.

Surface samples show rare compositional layering, commonly of unknown orientation, and a limited assemblage of possible cumulate textures. Drill-core samples show well-developed igneous compositional layering that varies in continuous sections from subhorizontal to subvertical over vertical intervals of a few meters. The rocks display a wide range of textural, phase, and size grading that are typical of cumulate assemblages. Thus, whereas submersibles may be extremely useful in prospecting for igneous cumulate suites, drilling is necessary for detailed petrologic studies of this type of material. In the future, detailed petrologic studies of cumulate suites in the oceanic crust will require better recovery than is presently available and sufficiently closely spaced holes to define the lateral dimensions of individual plutonic suites. Correlations between the holes drilled during Leg 153 are tenuous (Stevens, this volume) and it is possible that the igneous suites drilled are from separate plutons with lateral dimensions of less than the distances between the holes, about $2 \mathrm{~km}$.

Paleomagnetic studies of oriented samples drilled during Leg 153 provide some new insights into crustal accretion processes. Samples recovered in a $2 \mathrm{~km}$ linear array of holes parallel to the spreading axis (Sites 921-923) and at Site 924 located approximately along a spreading flow line all show intimately mixed normal and reversed magnetic polarity. This suggests that discrete gabbroic plutons were being intruded over a wide area during the last magnetic reversal. Magnetic polarity characteristics provide a basis for correlating units between holes even where recovery rate is rather low. At Sites 921924 this is important for recognizing magmatically similar, but temporally distinct, rock units from different holes and even in the same hole.

\section{Episodic and Steady-State Spreading}

The geologic history of the intersection massif at the Mid-Atlantic Ridge-Kane Transform intersection inferred from combined surface and subsurface geology and geophysics reveals a complex history of crustal extension and uplift that is not part of the current, over-generalized, textbook description of seafloor spreading. Seafloor spreading is traditionally viewed as magmatic construction at a diverging plate boundary with faulting sufficient to make rift valleys of various dimensions. The geology of the northern segment of the MARK area, however, suggests two very significant variations on this theme. First, faulting in some places must dominate over magmatic construction and, in fact, be sufficient to uplift and expose rocks from at least middle to deep crustal levels. Second, magmatic construction may be episodic with respect to crustal extension, with significant periods of time when plate separation must be accommodated solely by stretching and thinning of the axial lithosphere. These two points are closely related because the amount of crustal exposure that occurs will be a function of the amount of stretching and thinning of crustal units which, in turn, will depend upon the duration and kinematics of faulting.

At present, the episodic behavior of slow-spreading ridges is not clearly defined. Mid-Atlantic Ridge ridge segments have highly variable morphologies, fault structures, and neovolcanic zones. If plate separation is more or less uniform on the scale of about a million years, then discontinuous magmatism could result in surficial geology like that of the northern segment of the MARK area. Large-scale, asymmetrical crustal extension with little or no magmatism would have accommodated plate separation and lateral movement of the crust for a few hundred thousand years prior to the construction of the neovolcanic ridge. Magmatism could have occurred during the exten- sional period, but could not have been sufficient to bury the faulted mafic plutonic rocks of the western wall.

Alternatively, if magmatism was more or less constant through time, then an episode of large-scale crustal stretching and faulting must have occurred at some point prior to the development of the neovolcanic ridge. Rapid stretching events triggered by magmatic intrusion are thought to have produced some highly extended continental terrains (e.g., Lister and Davis, 1989; Lister and Baldwin, 1993).

Presently available constraints do not exclude the possibility of steady-state asymmetrical spreading (Dick et al., 1981; Tucholke and Lin, 1994). In this situation, plutonic material would be accreted to the footwall of a detachment system while volcanic material is added to the hanging wall. The geology of the northern spreading segment of the MARK area and adjacent Kane Transform suggests that, if this type of spreading has occurred, it has persisted for at least 4 m.y. (Auzende et al., 1993a). These questions pertaining to the nature of spreading (episodic or steady-state) and temporal relations between major faulting and magmatism in places like the northern segment of the MARK area can be resolved by detailed sampling and radiometric dating of basaltic and gabbroic rocks $<1 \mathrm{~m}$.y. old across the median valley.

\section{Evolution of an Oceanic Core Complex}

Figure 9 depicts a schematic evolution of a highly extended oceanic core complex (Karson, 1990) based on the geology of the intersection massif and inferences from Cordilleran core complexes (Wernicke and Axen, 1988; Lister and Davis, 1989; Reynolds and Lister, 1990). It depicts the evolution of a major crustal detachment that cuts through the entire thickness of the axial crust, which, near a spreading axis, would essentially comprise the lithosphere. Faulting on this scale is suggested by microseismic activity extending through the entire thickness of the crust and into the oceanic mantle of some Mid-Atlantic Ridge spreading centers (Toomey et al., 1988). In this model, isostatic uplift of the footwall domain results in dismemberment of the detachment surface and rotation of early deformation fabrics. Renewed magmatic activity in the axial region eventually truncates the detachment fault leaving the core complex stranded between "normal" crustal sections. The plutonic underpinnings of the massive neovolcanic ridge that lies just to the east of the detachment fault zone in the MARK area would truncate the faults zone at depth. Paleomagnetic constraints suggest that Sites 921-924, in the detachment foot wall, are $0.7-0.9$ m.y. old, whereas the neovolcanic ridge, which defines the present spreading axis, appears to be much younger ( $\sim 5$ k.y. old; Brown and Karson, 1988). In the northern part of the segment, these two sites are separated by an outcrop area of faulted mafic plutonic rocks that is $8-10 \mathrm{~km}$ wide. To the south, basaltic rocks also occupy the western median valley floor (Karson et al., 1987; Gente et al., 1991).

If the plutonic rocks are old deep crustal rock created at about the same time as the rest of the eastern edge of the intersection massif, a ridge jump or hiatus in magmatism may have occurred. If the plutonic rocks are much younger, say less than $104 \mathrm{yr}$, then more continuous accretion models would apply. Testing of these hypotheses must await detailed geochronology studies. If robust magmatism continues along the axis of the median valley, an intersection massif core complex would become isolated with the footwall structures of the massif on the North American Plate and the hanging wall structures on the African Plate.

More or less continuous stretching of crust composed of gabbroic rocks and serpentinite that has been intruded by synkinematic gabbroic plutons and diabase dikes is in accord with the complex history of intrusion, deformation and metamorphism recorded in the Site 921-924 drill cores. This type of steady-state spreading is supported by observations along the southern wall of the Kane Transform 


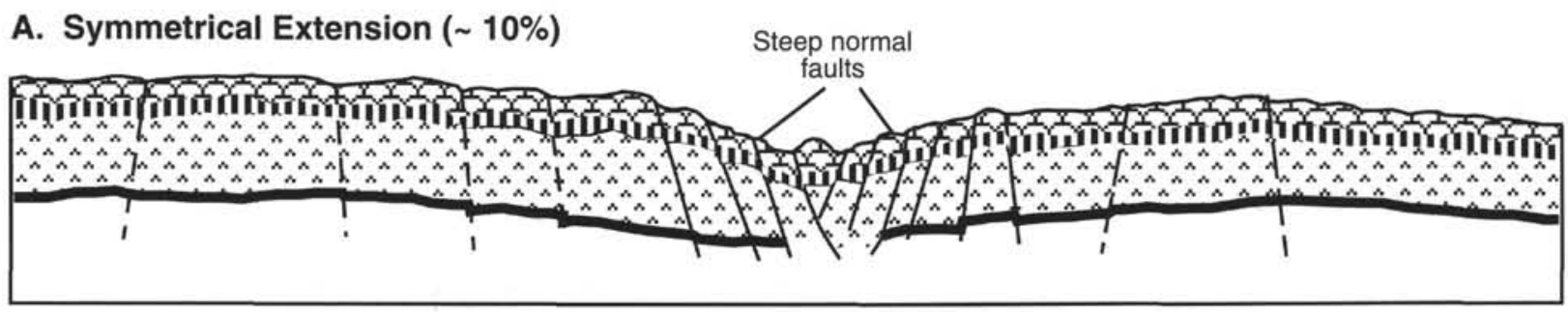

\section{B. Asymmetrical Extension ( 20\%)}

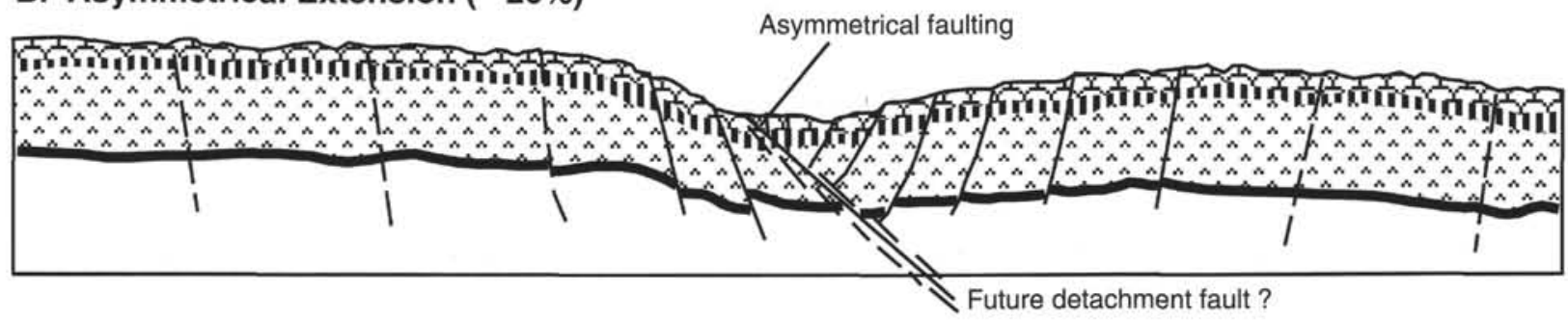

\section{Highly Asymmetrical Extension (50-100\%)}

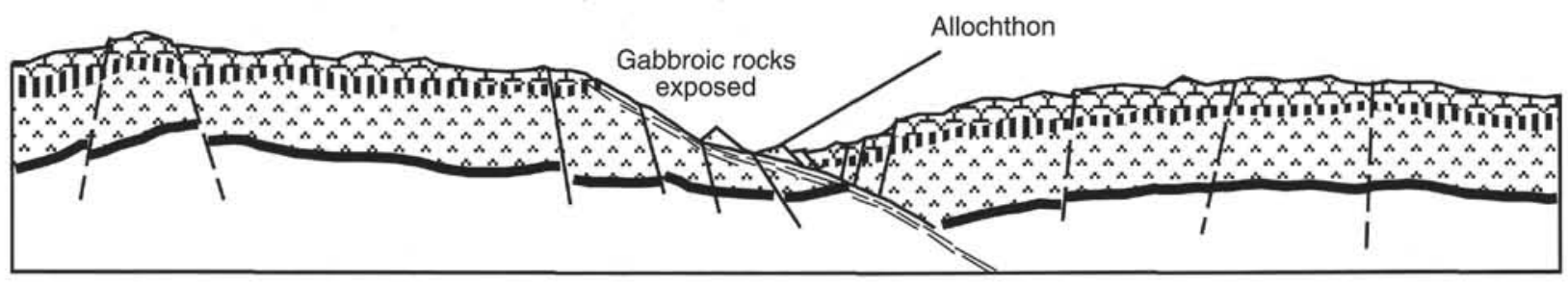

\section{Renewed Magmatic Activity}

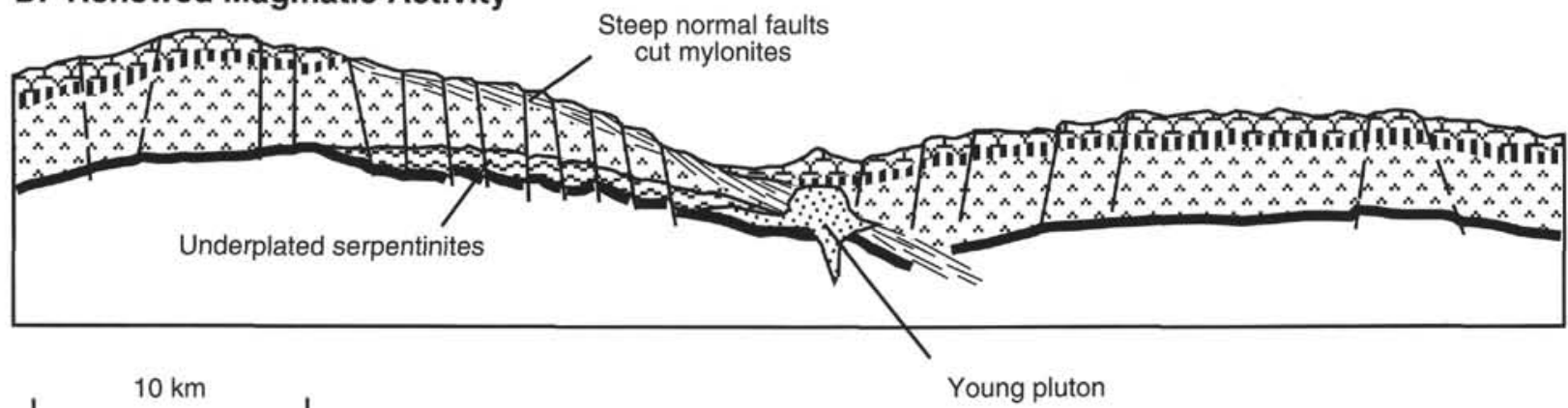

Figure 9. Evolution of an oceanic core complex inferred from relationships at various study areas along the Mid-Atlantic Ridge and the Kane Transform intersection massif. A. Symmetrical extension ( 10\%; inferred from apparent heaves of fault scarps) commonly found along the Mid-Atlantic Ridge (e.g., FAMOUS and AMAR areas near $39^{\circ} \mathrm{N}$ and Segment 2 of the MARK area). Only minor normal faulting disrupts oceanic crust formed by a robust magma budget. B. Asymmetrical rift with greater extension ( $20 \%)$ and crustal thinning. Asymmetrical rifts with this geometry also appear to be common on the Mid-Atlantic Ridge (e.g., TAG area at $26^{\circ} \mathrm{N}$ and Segment 3 of the MARK area). Major normal faults might develop in an environment of reduced or episodic magma budget. C. Development of a major crustal detachment fault accommodating large-magnitude extension (50\%-100\%) and thinning. Extensive exposures of middle to lower crustal and even serpentinized upper mantle rocks occur in the detachment footwall. Complex relations between faults and shear zones, allochthonous slices derived from various crustal levels, and synkinematic dikes and lavas are expected. D. Cross section of the intersection massif and adjacent axial region of the Mid-Atlantic Ridge in the MARK area (no vertical exaggeration). The highly stretched and thinned footwall of the detachment (core complex) is isostatically uplifted along steep normal faults and possibly underplated by serpentinized upper mantle rocks and/or gabbroic sills. In the median valley, basaltic lavas of the neovolcanic ridge cover the detachment footwall and are probably cut by young dike swarms and gabbroic plutons at depth. Oceanic core complexes might develop by extreme crustal extension during periods of waning magma supply, as shown by the sequence of panels over about $0.5-1.0 \mathrm{~m} . \mathrm{y}$. Alternatively, they might also develop by more or less continuous synkinematic intrusion and extensional deformation of the axial lithosphere with situations alternating between those shown in $\mathrm{C}$ and $\mathrm{D}$ on a time scale on the order of $10^{4} \mathrm{yr}$. 
(Auzende et al., 1993a) and has also been suggested for the evolution of ridge-transform intersection crust of the Southwest Indian Ridge (Dick et al., 1991).

The $8-10 \mathrm{~km}$ width of the detachment surface in the MARK area suggests a substantial period of plate separation during which little if any volcanic material was added to the footwall. Magmatism to the east of the spreading axis during this same interval cannot be ruled out. Paleomagnetic results indicate that at least part of the gabbros drilled at Sites 921-924 crystallized during the last period of reversed magnetization $(0.7-0.9 \mathrm{Ma})$. These ages fit with those calculated for these sites assuming constant and symmetrical spreading. The drill sites are $8-10 \mathrm{~km}$ from the center of the median valley and are thus located in crust at the distance predicted from the regional halfspreading rate. Thus, only half of the plate separation is accounted for by slip on this fault zone. Half of the spreading rate must be accounted for by some other process(es) in the central and/or eastern half of the spreading segment. Available geological and geophysical data suggest that magmatic accretion has dominated to the east of the spreading axis over the past $1 \mathrm{~m} . \mathrm{y}$. and may have produced a relatively thick crust (Morris and Detrick, 1991). Thus, the asymmetric morphology and geology of this ridge segment reflect highly asymmetrical processes of spreading on the time scale of $1 \mathrm{~m}$.y. Spreading west of the axis may have been primarily accommodated by slip on a major detachment system while spreading east of the axis may have involved mainly magmatic accretion. A similar asymmetric development has been inferred for continental extensional terrains and rifted margins (Lister et al, 1986).

Although this highly asymmetric spreading scheme seems possible, there are other possibilities. The age of volcanic terrains in the spreading axis and just to the east are not known and they could possibly be very young relative to the stretched crust to the west and bury older highly extended crust. If the position of the detachment fault zone has migrated westward, there may be stranded fragments of a major fault zone in the lower crust of the eastern median valley and valley wall (hanging wall domain). Thus, it is unclear if major detachment faulting occurred in discrete episodes of very limited or no magmatic construction, or if magmatism and faulting were coeval.

Some authors have suggested that the type of extreme stretching found in the intersection massif of the MARK area is confined to ridge-transform intersections (Karson and Dick, 1983; Dick et al., 1991; Tucholke and Lin, 1994). These processes may be responsible for the thinning of the seismically defined crust near fracture zones (Detrick and Purdy, 1980; White et al., 1984) as well as thinning of rock units (Fox and Stroup, 1981; Karson and Dick, 1983). Ridgetransform intersections are likely to be regions of especially low magma budget (Stroup and Fox, 1981; Fox and Gallo, 1986; but see Karson and Elthon, 1987), but low magma supply might also occur at other ridge segments far from transforms. Recent investigations of an asymmetrical ridge segment $100 \mathrm{~km}$ south of the Kane Transform, also in the MARK area (Fig. 1), show that the eastern median valley wall is a major detachment fault exposing a thick sequence of basaltic and diabasic rocks, possibly a juvenile core complex (J.A. Karson, S.D. Hurst, R.M. Lawrence, and SMARK Cruise Participants, unpubl. data). Thus, oceanic core complexes do not appear to be limited to ridge-transform intersection and may be widely developed in crust produced in slow-spreading ridges with variable magma budgets.

\section{CONCLUSIONS}

Integrated surface and subsurface investigations of the gabbroic rock units of the western median valley wall of the northern segment of the MARK area provide new insights into the evolution of this terrain. These studies permit an evaluation of major crustal volumes that provide significant advantages to the limitations of surficial or drilling perspectives alone. Although crustal-scale detachment faulting is inferred from surface studies, cored gabbroic rocks of the detachment footwall document a protracted history of syn- to post-crystallization deformation and metamorphism. This assemblage may have evolved near the locus of magmatism beneath the median valley floor prior to being uplifted and exposed. Despite the extensive low-angle normal faulting of the western median valley wall, paleomagnetic studies suggest that crustal materials have moved laterally to a distance predicted by symmetrical spreading at the half-rate constrained by regional magnetic anomalies. Regional geologic relations may be interpreted in terms of asymmetrical spreading with broadly coeval detachment faulting to the west and magmatic accretion to the east during the last $1 \mathrm{~m} . \mathrm{y}$. Alternatively, extreme crustal stretching during amagmatic spreading followed by an episode of magmatic accretion may have led to a similar geologic expression.

In any case, the geology of the northern spreading segment of the MARK area is radically different from that typically found along fast-spreading ridges or depicted in general representations of seafloor spreading. The internal structure the oceanic crust produced in this regime cannot have the simple layered structure expected in oceanic crust and is likely to be extremely complex in terms of its igneous, metamorphic, and deformational history.

\section{ACKNOWLEDGMENTS}

The authors thank the Leg 153 engineering, technical, and scientific staff for their contributions toward the success of this drilling effort. This work was supported primarily by USSSP grants $153-$ 2021A to J.A. Karson, and 153-20822A to R.M. Lawrence for postcruise data analysis. Dr. Steve Hurst and Dengliang Gao provided the preliminary sonar mosaic for the Site $921-924$ area. Reviews by M. Cannat, G. Piccardo, and an anonymous reviewer helped improve the presentation of these results. In addition, we thank the National Science Foundation Program in Marine Geology and Geophysics for its support of studies in the MARK area over the last decade. In particular, we acknowledge the support of grants OCE 89-20527 that supported the deep-tow up- and down-looking side-scan sonar study of the MARK area and supported Karson's participation in Nautile diving programs, and OCE 92-02261 that supported recent Alvin dives near the Leg 153 sites.

\section{REFERENCES}

Auzende, J.M., Cannat, M., Gente, P., Henriet, J.P., Juteau, T., Karson, J.A., Lagabrielle, Y., and Tivey, M.A., 1993a. A transect through 0-4 Ma oceanic crust: Nautile dives along the Kane Transform. RIDGE Events, 4:310.

Auzende, J.M., Tivey, M., Cannat, M., Gente, P., Henriet, J.P., Juteau, T., Karson, J.A., and Lagabrielle, Y., 1993b. First in situ exploration of the MAR South of the Atlantis Fracture Zone. C.R. Acad. Sci. Ser. 2, 316:1415-1422.

Bratt, S.R., and Purdy, G.M., 1984. Structure and variability of oceanic crust on the flanks of the East Pacific Rise between $11^{\circ}$ and $13^{\circ} \mathrm{N}$. J. Geophys. Res., 89:6111-6125.

Brown, J.R., and Karson, J.A., 1988. Variations in axial processes on the Mid-Atlantic Ridge: the median valley of the MARK area. Mar. Geophys. Res., 10:109-138.

Bryan, W.F., Humphris, S., Thompson, G., and Casey, J.F., 1994. Comparative volcanology of small eruptive centers in the MARK area. J. Geophys. Res., 99:2973-2984.

Cannat, M., 1993. Emplacement of mantle rocks in the seafloor at mid-ocean ridges. J. Geophys. Res., 98:4163-4172.

Cannat, M., Karson, J.A., Miller, D.J., et al., 1995. Proc. ODP, Init. Repts., 153: College Station, TX (Ocean Drilling Program).

Cannat, M., Mével, C., Maia, M., Deplus, C., Durand, C., Gente, P., Agrinier, P., Belarouchi, A., Dubuisson, G., et al., 1995. Thin crust, ultramafic exposures, and rugged faulting patterns at the Mid-Atlantic Ridge $\left(22^{\circ}-\right.$ $\left.24^{\circ} \mathrm{N}\right)$. Geology, 23:49-52.

Casey, J.F., Dewey, J.F., Fox, P.J., Karson, J.A., and Rosencrantz, E., 1981. Heterogeneous nature of oceanic crust and upper mantle: a perspective from the Bay of Islands Ophiolite Complex. In Emiliani, C. (Ed.), The Sea (Vol. 7) The Oceanic Lithosphere: New York (Wiley), 305-338. 
Christensen, N.I., 1982. Seismic velocities. In Carmichael, R.S. (Ed.), Handbook of Physical Properties of Rocks (Vol. 2): Boca Raton, FL (CRC Press), 1-228.

Christensen, N.I., and Salisbury, M.H., 1975. Structure and constitution of the lower oceanic crust. Rev. Geophys. Space Phys., 13:57-86.

Cormier, M.-H., Detrick, R.S., and Purdy, G.M., 1984. Anomalously thin crust in oceanic fracture zones: new seismic constraints from the Kane Fracture Zone. J. Geophys. Res., 89:10249-10266.

Crane, K., and Ballard, R.D., 1981. Volcanics and structure of the FAMOUS Narrowgate rift: evidence for cyclic evolution: AMAR 1. J. Geophys. Res., 86:5112-5124.

Delaney, J.R., Mogk, D.W., and Mottl, M.J., 1987. Quartz-cemented breccias from the Mid-Atlantic Ridge: samples of a high-salinity hydrothermal upflow zone. J. Geophys. Res., 92:9175-9192.

Deplus, C., Maia, M., Aslanian, D., and Gente, P., 1992. Segmentation of the Mid-Atlantic Ridge south of Kane fracture zone revealed by gravity anomalies. Results of Seadma 1 cruise. Eos, 73:568.

Detrick, R., Honnorez, J., Bryan, W.B., Juteau, T., et al., 1988. Proc. ODP, Init. Repts., 106/109: College Station, TX (Ocean Drilling Program).

Detrick, R.S., Buhl, P., Vera, E., Mutter, J., Orcutt, J., Madsen, J., and Brocher, T., 1987. Multi-channel seismic imaging of a crustal magma chamber along the East Pacific Rise. Nature, 326:35-41.

Detrick, R.S., Fox, P.J., Schulz, N., Pockalny, R., Kong, L., Mayer, L., and Ryan, W.B.F., 1988. Geologic and tectonic setting of the MARK area. In Detrick, R., Honnorez, J., et al., Proc. ODP, Init. Repts., 106/109: College Station, TX (Ocean Drilling Program), 15-22.

Detrick, R.S., Mutter, J.C., Buhl, P., and Kim, I.I., 1990. No evidence from multichannel seismic reflection data for a crustal magma chamber in the MARK area on the Mid-Atlantic Ridge. Nature, 347:61-64.

Detrick, R.S., and Purdy, G.M., 1980. The crustal structure of the Kane Fracture Zone from seismic refraction studies. J. Geophys. Res., 85:37593777.

Dick, H.J.B., Meyer, P.S., Bloomer, S., Kirby, S., Stakes, D., and Mawer, C., 1991. Lithostratigraphic evolution of an in-situ section of oceanic Layer 3. In Von Herzen, R.P., Robinson, P.T., et al., Proc. ODP, Sci. Results, 118: College Station, TX (Ocean Drilling Program), 439-538.

Dick, H.J.B., Thompson, G., and Bryan, W.B., 1981. Low angle faulting and steady state emplacement of plutonic rocks at ridge-transform intersections. Eos, 62:406.

Eberhart, G.L., Rona, P.A., and Honnorez, J., 1988. Geologic controls of hydrothermal activity in the Mid-Atlantic Ridge rift valley: tectonics and volcanics. Mar. Geophys. Res., 10:233-259.

Fox, P.J., 1972. The geology of some Atlantic fracture zones, Caribbean escarpments, and the nature of the oceanic basement and crust [Ph.D. dissert.]. Columbia Univ., New York.

Fox, P.J., and Gallo, D.G., 1986. The geology of North Atlantic transform plate boundaries and their aseismic extensions. In Tucholke, B.E., and Vogt, P. (Eds.), The Western North Atlantic Region. Geol. Soc. Am., DNAG, N:111-124.

Gente, P., Mével, C., Auzende, J.-M., Karson, J.A., and Fouquet, Y., 1991. An example of a recent accretion on the Mid-Atlantic Ridge: the Snake Pit neovolcanic ridge (MARK area: $23^{\circ} 22 \mathrm{~N}$ ). Tectonophysics, 190:1-29.

Gente, P., Pockalny, R.A., Durand, C., Deplus, C., Maïa, M., Ceuleneer, G., Mével, C., Cannat, M., and Laverne, C., 1995. Characteristics and evolution of the segmentation of the Mid-Atlantic Ridge between $20^{\circ} \mathrm{N}$ and $24^{\circ} \mathrm{N}$ during the last 10 million years. Earth Planet. Sci. Lett., 129:5571.

Gillis, K.M., Thompson, G., and Kelley, D.S., 1993. A view of the lower crustal component of hydrothermal systems at the Mid-Atlantic Ridge. $J$. Geophys. Res., 98:19597-19619.

Grindlay, N.R., Fox, P.J., and Macdonald, K.C., 1991. Second-order ridge axis discontinuities in the South Atlantic: morphology, structure, and evolution. Mar. Geophys. Res., 13:21-49.

Hess, H.H., 1962. History of ocean basins. In Buddington, A.F., Engel, A.E.J., et al. (Eds.), Petrologic Studies (Buddington Volume), Mem.Geol. Soc. Am., 599-620.

Karson, J.A., 1990. Seafloor spreading on the Mid-Atlantic Ridge: implications for the structure of ophiolites and oceanic lithosphere produced in slow-spreading environments. In Malpas, J., Moores, E.M., Panayiotou, A., and Xenophontos, C. (Eds.), Proceedings of the Symposium "Troodos 1987." Geol. Surv. Dep. Nicosia, Cyprus, 547-555.

Karson, J.A., Delaney, J.R., Spiess, F.N., Hurst, S., Lawhead, B., Bigger, S., Naidoo, D., and Gente, P., 1992. Deep-tow observations at the eastern intersection of the Mid-Atlantic Ridge and the Kane Fracture Zone. Eos, 73:552.
Karson, J.A., and Dick, H.J.B., 1983. Tectonics of ridge-transform intersections at the Kane fracture zone. Mar. Geophys. Res., 6:51-98.

Karson, J.A., and Elthon, D., 1987. Evidence for variations in magma production along spreading centers: a critical appraisal. Geology, 15:127-131.

Karson, J.A., and Fox, P.J., 1986. Geological and geophysical investigation of the Mid-Cayman spreading centre: seismic velocity measurements and implications for the constitution of layer 3. Geophys. J. R. Astron. Soc., 85:389-411.

Karson, J.A., and Rona, P.A., 1990. Block tilting, transfer faults, and structural control of magmatic and hydrothermal processes in the TAG area, Mid-Atlantic Ridge $26^{\circ}$ N. Geol. Soc. Am. Bull., 102:1635-1645.

Karson, J.A., Thompson, G., Humphris, S.E., Edmond, J.M., Bryan, W.B., Brown, J.R., Winters, A.T., Pockalny, R.A., Casey, J.F., Campbell, A.C., Klinkhammer, G., Palmer, M.R., Kinzler, R.J., and Sulanowska, M.M., 1987. Along-axis variations in seafloor spreading in the MARK area. Nature, 328:681-685.

Karson, J.A., and Winters, A.T., 1992. Along-axis variations in tectonic extension and accommodation zones in the MARK area, Mid-Atlantic Ridge $23^{\circ} \mathrm{N}$ latitude: ophiolites and their modern oceanic analogues. In Parson, L.M., Murton, B.J., and Browning, P. (Eds.), Ophiolites and Their Modern Oceanic Analogues. Geol. Soc. Spec. Publ. London, 60:107-116.

Kelley, D.S., and Delaney, J.R., 1987. Two-phase separation and fracturing in mid-ocean ridge gabbros at temperatures greater than $700^{\circ} \mathrm{C}$. Earth Planet. Sci. Lett., 83:53-66.

Kelley, D.S., Gillis, K.M., and Thompson, G., 1993. Fluid evolution in submarine magma-hydrothermal systems at the Mid-Atlantic Ridge. J. Geophys. Res., 98:19579-19596.

Kong, L.S.L., Detrick, R.S., Fox, P.J., Mayer, L.A., and Ryan, W.F.B., 1989. The morphology and tectonics of the MARK area from Sea Beam and MARC 1 observations (Mid-Atlantic Ridge $23^{\circ} \mathrm{N}$ ). Mar. Geophys. Res., 10:59-90.

Kuo, B.-Y., and Forsyth, D.W., 1988. Gravity anomalies of the ridge transform system in the South Atlantic between $31^{\circ}$ and $34^{\circ} \mathrm{S}$. Mar. Geophys. Res., 10:205-232.

Lin, J., Purdy, G.M., Schouten, H., Sempéré, J.-C., and Zervas, C., 1990. Evidence from gravity data for focussed magmatic accretion along the Mid-Atlantic Ridge. Nature, 344:627-632.

Lister, G.S., and Baldwin, S.L., 1993. Plutonism and the origin of metamorphic core complexes. Geology, 21:607-610.

Lister, G.S., and Davis, G.A., 1989. The origin of metamorphic core complexes and detachment faults formed during Tertiary continental extension in the Northern Colorado River region, U.S.A. J. Struct. Geol., 11:65-94.

Lister, G.S., Etheridge, M.A., and Symonds, P.A., 1986. Detachment faulting and evolution of passive continental margins. Geology, 14:246-250.

Macdonald, K.C., 1986. The crest of the Mid-Atlantic Ridge: models for crustal generation processes and tectonics. In Tucholke, B.E., and Vogt, P. (Eds.), The Western North Atlantic Region. Geol. Soc. Am., DNAG, $\mathrm{N}: 54-58$.

Macdonald, K.C., Fox, P.J., Perram, L.J., Eisen, M.F., Haymon, R.M., Miller, S.P., Carbotte, S.M., Cormier, M.-H., and Shor, A.N., 1988. A new view of the mid-ocean ridge from the behaviour of ridge-axis discontinuities. Nature, 335:217-225.

Macdonald, K.C., and Luyendyk, B.P., 1977. Deep-tow studies of the structure of the Mid-Atlantic Ridge crest near $37^{\circ} \mathrm{N}$ (FAMOUS). Geol. Soc. Am. Bull., 88:621-636.

Marion, E., 1993. Interactions croute oceanique profonds-eau de mer dans les gabbros de la zone MARK (Mid-Atlantic Ridge/Kane Fracture Zone) [Ph.D. thesis]. Univ. Pierre et Marie Curie, Paris.

Marion, E., Mével, C., and Cannat, M., 1991. Evolution of oceanic gabbros from the MARK/Kane fracture intersection massif. Terra Abstr., 3:310.

Melson, W.G., Rabinowitz, P.D., et al., 1979. Init. Repts. DSDP, 45: Washington (U.S. Govt. Printing Office).

Mével, C., Cannat, M., Gente, P., Marion, E., Auzende, J.-M., and Karson, J.A., 1991. Emplacement of deep crustal and mantle rocks on the west median valley wall of the MARK area (MAR $23^{\circ} \mathrm{N}$ ). Tectonophysics, 190:31-53.

Miyashiro, A., Shido, F., and Ewing, M., 1970. Petrologic models for the Mid-Atlantic Ridge. Deep-Sea Res. Part A, 17:109-125.

1971. Metamorphism in the Mid-Atlantic Ridge near $24^{\circ}$ and $30^{\circ}$ N. Philos. Trans. R. Soc. London A, 268:589-603.

Moores, E.M., and Vine, F.J., 1971. The Troodos Massif, Cyprus and other ophiolites as oceanic crust: evaluation and implications. Philos. Trans. $R$. Soc. London A, 268:443-466. 
Morris, E., and Detrick, R.S., 1991. Three dimensional analysis of gravity anomalies in the MARK area (MAR, $\left.23^{\circ} \mathrm{N}\right)$. J. Geophys. Res., 96:43554366.

Morris, E., Detrick, R.S., Minshull, T.A., Mutter, J.C., White, R.S., Su, W., and Buhl, P., 1993. Seismic structure of oceanic crust in the western North Atlantic. J. Geophys. Res., 98:13879-13903.

Mutter, J.C., and Karson, J.A., 1992. Structural processes at slow-spreading ridges. Science, 257:627-634.

Nicolas, A., 1989. Structure of Ophiolites and Dynamics of the Oceanic Lithosphere: Dordrecht (Kluwer).

Patriat, P., Deplus, C., Rommevaux, C., and Sloan, H., 1991. SARA: evolution of the axial segmentation of the Mid Atlantic Ridge between $28^{\circ}$ and $29^{\circ} \mathrm{N}, 0-10$ Ma. Eos, 72:477.

Pockalny, R.A., Detrick, R.S., and Fox, P.J., 1988. Morphology and tectonics of the Kane Transform from Sea Beam bathymetry data. J. Geophys. Res., 93:3179-3193.

Purdy, G.M., and Detrick, R.S., 1986. Crustal structure of the Mid-Atlantic Ridge at $23^{\circ} \mathrm{N}$ from seismic refraction studies. J. Geophys. Res., 91:3739-3762.

Purdy, G.M., Rabinowitz, P.D., and Schouten, H., 1979. The Mid-Atlantic Ridge at $23^{\circ} \mathrm{N}$ : bathymetry and magnetics. In Melson, W.G., Rabinowitz, P.D., et al., Init. Repts. DSDP, 45: Washington (U.S. Govt. Printing Office), 119-128.

Purdy, G.M., Sempéré, J.-C., Schouten, H., Dubois, D.L., and Goldsmith, R., 1990. Bathymetry of the Mid-Atlantic Ridge, $24^{\circ}-31^{\circ} \mathrm{N}$ : a map series. Mar. Geophys. Res., 12:247-252.

Reynolds, S.J., and Lister, G.S., 1990. Folding of mylonitic zones in Cordilleran metamorphic core complexes: evidence form near the mylonitic front. Geology, 18:216-219.

Schulz, N.J., Detrick, R.S., and Miller, S.P., 1988. Two- and three-dimensional inversions of magnetic anomalies in the MARK area (Mid-Atlantic Ridge, $\left.23^{\circ} \mathrm{N}\right)$. Mar: Geophys. Res., 10:41-57.

Sempéré, J.-C., Purdy, G.M., and Schouten, H., 1990. Segmentation of the Mid-Atlantic Ridge between $24^{\circ} \mathrm{N}$ and $30^{\circ} 40$ N. Nature, $344: 427-431$.

Severinghaus, J.P., and Macdonald, K.C., 1988. High inside corners at ridgetransform intersections. Mar. Geophys. Res., 9:353-367.

Sinton, J.M., and Detrick, R.S., 1992. Mid-ocean ridge magma chambers. J. Geophys. Res., 97:197-216.
Stakes, D.S., Shervais, J.W., and Hopson, C.A., 1984. The volcanic-tectonic cycle of the FAMOUS and AMAR valleys, Mid-Atlantic Ridge $\left(36^{\circ} 47 \mathrm{~N}\right)$ : evidence from basalt glass and phenocryst compositional variations for a steady state magma chamber beneath the valley mid-sections, AMAR 3. J. Geophys. Res., 89:6995-7028.

Stroup, J.B., and Fox, P.J., 1981. Geologic investigations in the Cayman Trough: evidence for thin oceanic crust along the Mid-Cayman Rise. J. Geol., 89:395-420.

Toomey, D.R., Purdy, G.M., Solomon, S.C., and Wilcock, W.S.D., 1990. The three-dimensional seismic velocity structure of the East Pacific Rise near latitude $9^{\circ} 30$ N. Nature, 347:639-645.

Toomey, D.R., Solomon, S.C., and Purdy, G.M., 1988. Microearthquakes beneath the median valley of the Mid-Atlantic Ridge near $23^{\circ} \mathrm{N}$ : tomography and tectonics. J. Geophys. Res., 93:9093-9112.

Tucholke, B.E., and Lin, J., 1994. A geological model for the structure of ridge segments in slow-spreading ocean crust. J. Geophys. Res., 99:11937-11958.

van Andel, T.H., Phillips, J.D., and Von Herzen, R.P., 1969. Rifting origin for the Vema fracture zone in the North Atlantic. Earth. Planet. Sci. Lett., 5:296-300.

Vera, E.E., Mutter, J.C., Buhl, P., Orcutt, J.A., Harding, A.J., Kappus, M.E., Detrick, R.S., and Brocher, T.M., 1990. The structure of 0- to 0.2-m.y.old oceanic crust at $9^{\circ} \mathrm{N}$ on the East Pacific Rise from expanded spread profiles. J. Geophys. Res., 95:15529-15556.

Wernicke, B.P., and Axen, G.J., 1988. On the role of isostasy in the evolution of normal fault systems. Geology, 16:848-451.

White, R.S., Detrick, R.S., Sinha, M.C., and Cormier, M.H., 1984. Anomalous seismic crustal structure of oceanic fracture zones. Geophys. J. R. Astron. Soc., 79:779-798.

Date of initial receipt: 19 July 1995

Date of acceptance: 5 March 1996

Ms 153SR-005 